\title{
Non-marine algae of Australia: 1. Survey of colonial gelatinous blue-green macroalgae (Cyanobacteria)
}

\author{
Stephen Skinner and Timothy J. Entwisle
}

\begin{abstract}
Skinner, S. and Entwisle, T.J. (Royal Botanic Gardens Sydney, Mrs Macquaries Road, Sydney NSW 2000, Australia. e-mail: tim.entwisle@rbgsyd.nsw.gov.au) 2001. Non-marine algae of Australia: 1. Survey of colonial gelatinous blue-green macroalgae (Cyanobacteria). Telopea 9(3): 573-599. Non-planktonic freshwater and terrestrial blue-green algae (Cyanobacteria) large enough to be noticeable even to casual observers, are frequently encountered in Australia, but appear only occasionally in the literature. Sixteen species of gelatinous colonial blue-green algae (Cyanobacteria) from Australia, are documented here. Two species - Nostoc borzioides and Rivularia concentrica - are new to science, and nine (Aphanothece caldariorum Richter, A. pallida (Kützing) Rabenhorst; Nostochopsis lobatus H.C. Wood ex Bornet \& Flahault; Rivularia aquatica de Wilde; Gloeotrichia pilgeri Schmidle; Dichothrix gypsophila (Kützing) Bornet \& Flahault; Nostoc flagelliforme Berkley \& Curtis; Nostoc pruniforme (L.) C. Agardh ex Bornet \& Flahault; Nostoc gelatinosum Schousboe in Bornet) are newly recorded from Australia. The others are Rivularia beccariana; Cylindrospermum licheniforme; Cylindrospermum stagnale; Nostoc commune and Nostoc verrucosum. Keys to the genera and species occurring in Australia are provided.
\end{abstract}

\section{Introduction}

This is the first of an occasional series of papers documenting new algal records and new taxa from non-marine habitats in Australia. The information is floristic rather than monographic, responding to an urgent need for information about the diversity of algae in freshwater and terrestrial habitats in Australia. The descriptions and illustrations are from Australian material, while protologues or authoratitive oversees descriptions have been consulted. We present a selection of locality records from throughout the continent. While comprehensive systematics studies are essential to fully assess endemism, rarity and weediness, and to reveal phylogenies and biogeographic patterns, the delineation and nomenclature of species is of immediate concern. Floristic documentation is required now for the adequate conservation, management and appreciation of non-marine algae in Australia.

The prosaic term 'non-marine' is complementary to the term 'marine' as used in The Marine Benthic Flora of Southern Australia (Womersley 1984). The non-marine algae are those that live outside the direct influence of marine waters. This excludes algae of intertidal saltmarshes and estuarine rivers but not algae growing in essentially nonmarine habitats (e.g. streams, caves, trees) subject to occasional marine spray.

This research was funded through the NSW Biodiversity Strategy

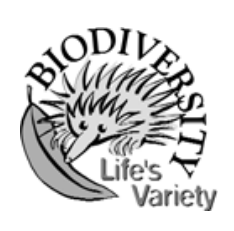


While some genera extend across this boundary (e.g. Vaucheria, Cladophora), very few species do so (e.g. Bostrychia harveyi Montagne, Enteromorpha intestinalis (L.) Link). Like the term algae itself, 'non-marine' is a term of convenience. 'Macroalgae' are those that can be easily observed under field conditions, either individually like Cladophora species (the blanket weeds) or collectively like colonies of Nostoc commune (Star Jelly or Snot).

Examples of macroalgal taxa may be found in all four orders of Cyanobacteria. Those cyanobacteria that have a colonial form through the congress of their cells or trichomes within a gelatinous or mucilaginous mass have not received due attention in Australia. They are not uncommon on soil, as epiphytes on aquatic vegetation or as part of the flora of waterfalls, rapids and river margins. These habitats have been undercollected until recently, greater interest being taken in the planktonic algal floras of pondages and man-made water storages. Represented here are three of the four orders of Cyanobacteria, the Chroococcales, the Nostocales and the Stigonematales. Aphanothece species (Chroococcales) are common and microscopic members of the plankton and benthos in Australian waters (Baker \& Fabbro 1999). The two taxa discussed here are terrestrial or semi-terrestrial and form macroscopic gelatinous aggregates. Nostochopsis lobatus H.C.Wood ex Bornet \& Flahault (Stigonematales) forms aquamarine gelatinous masses, often as big as grapes, on the walls of waterfalls and spillways, especially in tropical areas. The remaining taxa, forming slippery or gluey coating, small to large gelatinous beads or rubbery crusts in benthic, epiphytic, marginal aquatic or terrestrial habitats, belong to the Nostocales. While many of the Oscillatoriales qualify as macroalgae, their colonies are often fibrous or cartilaginous rather than gelatinous.

\section{Methods}

Specimens from herbaria in Melbourne (MEL), Sydney (NSW), and selected material from Brisbane (BRI) and Hobart (HO) were examined, including recent collections by the authors. As the specimens were of different ages and states of preservation and the information with them was often rudimentary, we have concentrated on using characteristics which can be obtained from the dried, pickled or slide material for our determinations. Literature records of most species from Australia are unvouchered and inadequately documented. For this reason we have not been able to accept many previous reports of species. While we recognise the importance to modern interpretation of taxa of accurate and comprehensive field observation, and the monitoring of organisms in culture, such methods are beyond the scope of this exercise the aim of which is primarily to broaden the baseline so that such work may be pursued in the future.

The keys we provide include only those species we cover in the paper. We have chosen to limit the present study to macroalgae, those where the growth habit is sufficiently conspicuous to be noticed as an entity in the field; microalgae (and many planktonic forms) have been deliberately excluded (but see Baker \& Fabbro 1999), and so in this sense the grouping is a functional and practical one. The taxa we recognise represent our best summary based on current knowledge of macroalgae in these groups.

In general type specimens have not been examined in this study. Type material of many freshwater algae may be of little value, as diagnostic features may become obscured or not be preserved in dried specimens. Locating types can be difficult or impossible, many were in German herbaria and were destroyed in WWII, and designations are often obscure. The descriptions in Bornet \& Flahault (1886-1888), the starting point for nomenclature in most of this group, have been consulted by us where applicable, and original descriptions sought in other cases. The next principal 
reference used was Geitler (1932), and comparison was made to Prescott (1951), Desikachary (1959) and, for Chroococcales, Komárek \& Anagnostidis (1999). This most recent monograph does not specify type specimens, and presents a carefully worded justification for the comparison of specimens with published descriptions rather than Types or culture strains. We are presenting descriptions and illustrations based on recent Australian collections.

Algae collected by the authors were processed in the following manner. Aquatic specimens were placed with water from the collecting site into $30 \mathrm{ml}$ or $60 \mathrm{ml}$ plastic screw-top bottles. Terrestrial specimens were usually dried and kept in a paper bag or folded paper. Upon return from the field, the aquatic samples were kept in a domestic refrigerator (usually for a maximum of 24 hours) until the addition of $5 \%$ commercial formalin. Some days or weeks later, and after preparing dried specimens and permanent microscope mounts, the remaining material was transferred to $70 \%$ ethanol with $5 \%$ glycerol (avoiding long-term storage in formalin for Occupational Health and Safety reasons). Occasionally specimens were placed directly into $70 \%$ ethanol (without the intervening formalin fixation). Such material is less well-preserved but usually still of scientific value.

Semi-permanent microscope preparations were stained with $1 \%$ aniline blue (with $4 \%$ molar $\mathrm{HCl}$ ) and mounted in 10\% Karo Corn Syrup (with $0.25 \%$ phenol or formalin to stop bacterial growth), with $40 \%$ Karo Corn Syrup (with $0.25 \%$ phenol or formalin) added to the side of the coverslip during drying.

The use of the orthograph 'heterocyte' in place of 'heterocyst', in line with practice recommended by the IAC (Mollenhauer et al. 1994) is followed here.

\section{Taxonomy}

\section{Key to genera}

1 Plants with individual cells often in groups of two or more cells in concentric envelopes, especially towards the outside of the thallus

$1^{*}$ Plants with cells in trichomes

2 Trichomes apparently heterotrichous, not confined in sheaths, with true branching; heterocytes scattered, often lateral, or pedicellate when terminal 2. Nostochopsis

2* Trichomes homotrichous, usually in sheaths, without true branching; heterocytes either terminal to whole trichome or intercalary, occasionally absent in some trichomes in a colony ............. 3

3 Trichomes tapering from basal heterocytes; false branching and hairs present ....................... 4

3* Trichomes more or less even in diameter throughout; fragmentation but no false branching occurring, and without hairs

4 Trichomes with at least one prominent akinete directly adjacent to the heterocyte when mature 4. Gloeotrichia

4* Trichomes without akinetes directly adjacent to the basal heterocyte 5

5 Thallus of radiating or parallel filaments wholly enclosed in a colony of distinct shape 3. Rivularia

$5^{*}$ Thallus a subdichotomously branched system of filaments in a spreading colony, often with other algae

5. Dichothrix

6 Trichomes forming a skin on growing surfaces; vegetative cells uniformly cylindrical; prominent ovate akinete immediately adjacent to heterocyte 6. Cylindrospermum

6* Trichomes embedded in a defined gelatinous globose, irregular crustose or wire-like structure; vegetative cells barrel-shaped, subglobose rarely cylindrical; akinetes similar in size and shape to vegetative cells not directly associated with heterocytes

7. Nostoc 


\section{Chroococcales: Synechococcaceae}

\section{Aphanothece Nägeli}

One of several genera with individual cells in gelatinous masses, which can become macroscopic. Aphanothece has cell division in one plane perpendicular to the long axis of the cell, but cells change orientation shortly afterwards thus becoming randomly dispersed within the matrix. This manner of division distinguishes it from Rhabdoderma and Rhabdogloea, which maintain orientation, or Gloeocapsa in the Microcystaceae, which has regular cell division in three planes. Gloeothece species, planktic or aerial, have envelopes around all cells in the thallus, while those in Aphanothece either have no envelopes (plankters) or have concentric envelopes well developed among cells at the outsides of the thallus and absent in the interior (terrestrial taxa) (Komárek \& Anagnostidis 1999).

Four species of Aphanothece have been recorded previously from Australia, either microalgal or unvouchered. (Day et al. 1995; Entwisle \& Nairn 1999). The two taxa discussed below, both new records for Australia, are semi-terrestrial, growing either in permanently or transiently saturated soil.

\section{Key to species of Aphanothece}

1 Cells cylindrical, often sigmoid, diameter c. $1 \mu \mathrm{m}$ 1a. A. caldariorum

$1 *$ Cells ovoid, diameter $3.5-5 \mu \mathrm{m}$ 1b. A. pallida

1a. Aphanothece caldariorum P.G. Richt., Hedwigia 20: 192 (1880).

Colonies of mealy but densely aggregated mucilage, olive-green to blue-green, on wet rock. Cells cylindrical to curved, blue-green, single or pairs, free in main body of matrix, in concentric envelopes at margins, 5.0-8.5 $\mu \mathrm{m}$ long, 1-1.5 $\mu \mathrm{m}$ diam; envelopes oval, lamellate, clear, concentric and close-fitting, 3.4-4.5 $\mu \mathrm{m}$ across. Nannocytes not seen. (Fig. 1, h)

Distribution and ecology: cosmopolitan. In Australia found in the drip and splash zone on the back wall of a waterfall, on mixed sandstone and limestone.

Notes: some cells showed a refractive granule either off-centre or in one pole, but this was not a consistent character. Otherwise the collection fits the description in Komárek \& Anagnostidis (1999). The accompanying sheathed and gelatinous diatoms may have contributed to the colour.

Specimen examined: New South Wales: Central Coast: Gap Creek Falls, Olney State Forest, Cherry 275, 10 Jul 2000 (NSW).

1b. Aphanothece pallida (Kütz.) Rabenh., Kryptogamenflora von Sachsen 1: 76 (1863), q.v.

[?] Microhaloa pallida Kützing, Tab. Phyc. I: 5 (1849).

Colonies extensive, gelatinous and olive-green, terrestrial. Cells ovoid, becoming spherical after division, olive to blue-green, grainy, free in the main body of the matrix, in concentric envelopes and closely packed at margins, 7.0-10.5 $\mu \mathrm{m}$ long, 3.5-6.0 $\mu \mathrm{m}$ in diameter. Envelopes clear, sometimes yellowish at outsides, concentric and closely appressed, inner ones 9.5-12 $\mu \mathrm{m}$ across. Nannocytes not seen. (Fig. $1 \mathrm{a}-\mathrm{c}$ ).

Distribution and ecology: cosmopolitan in temperate regions. In Australia found growing on damp soil or sand, or with other marginal aquatic algae (Cylindrospermum) along creek banks. 


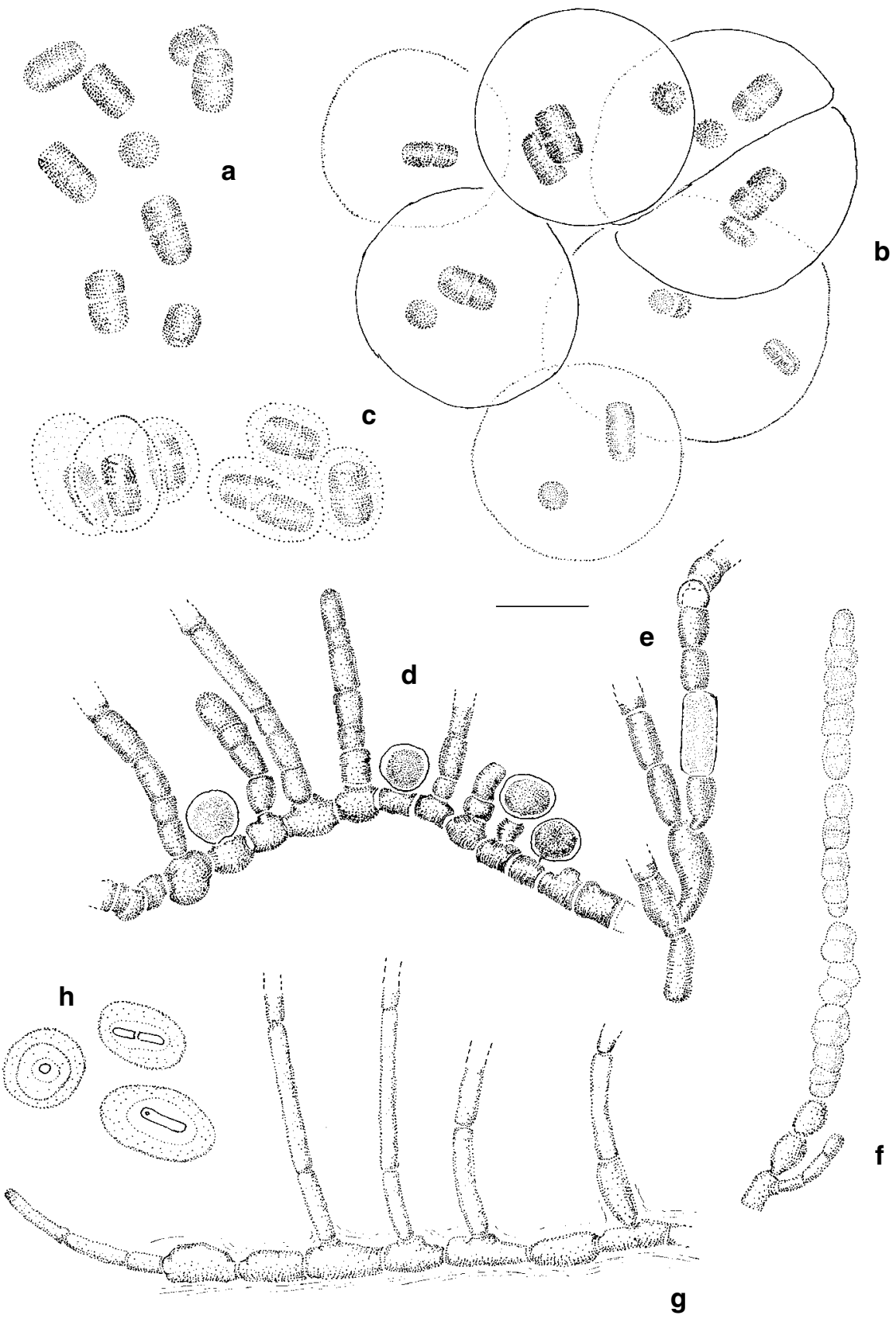

Fig.1. Chroococcales: a-c, Aphanothece pallida a, cells in inner colony; $\mathbf{b}$, encapsulated cells towards the margin; c, large capsules at outside of colony (K10892/2); h, A. caldariorum (Cherry 275); Stigonematales: d-g Nostochopsis lobatus, d, axis with lateral and pedicelate heterocytes (May A1004); e, intercalary heterocyte; f, axis with comb-like group of laterals (Entwisle 2342b); g, row of hormogones (BRI 701828). Scale bar $=10 \mu \mathrm{m}$. 
Notes: The Victorian specimen fits the description in Komárek \& Anagnostidis (1999). Very wide spherical or hemispherical sheaths, each with a pair of cells, were found in patches at the margins of thalli. These may be propagules. The dimensions of the New South Wales specimen were towards the smaller end of the range.

Specimens examined: New South Wales: Northern Tablelands: Deer Park River, Waterfall Way, Cherry (Skinner 0156), 24 May 2000 (NSW). Victoria: sand-dunes near Grannies Grave, $250 \mathrm{~m}$ along Terang Street-Lady Bay track, Warrnambool, L.E G. Kraft K10982.2, 23 Jul 2000 (NSW).

\section{Stigonematales: Nostochopsaceae}

\section{Nostochopsis Wood ex Bornet \& Flahault}

Previously known in Australia from a single undocumented record (Day et al. 1995; Entwisle \& Nairn 1999), Nostochopsis includes at least three species worldwide (Desikachary 1959).

Nostochopsis lobatus H.C. Wood ex Bornet \& Flahault, Ann. Sci. Nat., Bot., sér. 7, 5: 80 (1887).

Colonies encrusting or inflated and spreading on moist soil or wet rock $3-5 \mathrm{~cm}$ or more across, blue-green to greenish black. Trichomes in two parts: branching sections, with subglobose, or broadly elliptical (sometimes pyriform) cells, 3.6-6.0 $\mu \mathrm{m}$ diam.; and unbranched sections, arising from the cells of the branching sections, with cylindrical cells, L/D 2-6, 1.2-2.4(-3.6) $\mu \mathrm{m}$ diam., the end cell rounded terminally; sheath faintly but clearly visible in the branching section, becoming diffuse in cylindrical sections, occasionally fragmented, or thickened and stained yellow; heterocytes intercalary in both sections, or lateral to cells in branching sections or on short one- to three-celled pedicels from the branching sections; intercalary heterocytes ovate, 7.2-12 $\mu \mathrm{m}$ long, 6.0-7.2 $\mu \mathrm{m}$ diam., with two pores; lateral and pedicellate heterocytes hemispherical to spherical, sometimes oblique, 6.0-7.2 $\mu \mathrm{m}$ diam. Hormogonia arising in branching sections, 2-8(-10) cells (sometimes more) similar in size to subglobose vegetative cells but with thickened walls (sometimes including small intercalary heterocytes). (Fig. $1 \mathrm{~d}-\mathrm{g}$ ).

Distribution and ecology: known in Australia from central northern New South Wales to north-eastern Queensland, but probably more widespread. Reported from many parts of the world. Usually attached to rocks in streams, but also spreading on moist soil in flowerpots (G.T. Kraft pers. comm.). Some Australian specimens (Cribb 687.58 and Cribb 19 Dec 1963) show lime accumulation. There are no records among our material of the free-floating habit noted by Desikachary (1959) and Anagnostides \& Komárek (1990).

Notes: the range of form in this taxon is substantial. Some specimens, like the Reynolds Creek material show the dendroid branching pattern illustrated by many authors, and short cylindrical sections which may become secondarily branch initiating. Other specimens (e.g. Entwisle 2342b, Entwisle 2258, \& BRI 701834) show a more one-sided, comb-like development of much longer non-branching sections which infrequently revert to the branching form and thus differ from the commonly reported morphology of N. lobatus. Sheath and Cole (1996) however illustrate a similar form, which they accept as N. lobatus from Fiji.

Lateral branches (and pedicels for heterocytes) arise perpendicular to the main axis by 'lateral $\mathrm{T}^{\prime}$ branching as described in Anagnostidis and Komárek (1990, p. 13). A pseudoparenchymatous crust of cells similar to those of the branch initiating sections but without separation into trichomes, may develop at the surface when thickening of the sheaths takes place. 
Australian material differs from $N$. hansgirgi in the morphology and arrangement of cells. N. radicans is similar but differs in the absence of intercalary heterocytes and in its apparently three-layered development.

Specimens examined: Queensland: Gap Ck, Cunninghams Gap, Cribb s.n., 27 Jan 1964 (BRI 701835); Reynolds Ck, Cribb 21.4 (determined by F. Drouet, 1949), 30 July 1949 (BRI); Mt. Crosby Weir, Cribb s.n., 9 Sept 1963, 31 Aug 1964, 19 July 1971 (BRI 701834, 701832, 701828); Obi Obi Ck, Cribb s.n., 26 Jan 1969 (BRI 701831); Carneys Ck, Cribb s.n., 19 Dec 1963 (BRI 701833); Carnarvon Gorge, Cribb 687.58, 14 Aug 1969 (BRI); Pine Mountain district, Cribb 920.2, 2 Jan 1981 (BRI); Cedar Creek Falls, Conway National Park area (W of Park), $20 \mathrm{~km}$ by road from Proserpine, Entwisle 2258, 9 Sept 1993 (MEL); Murray R, Murray Falls, in river below falls, $25 \mathrm{~km}$ NW of Cardwell, off Bruce Highway (Cardwell-Tully), Entwisle 2342b, 12 Sept 1993 (MEL); Millstream Falls, below the falls, Cribb s.n., 10 Jan 1973 (BRI 701827).

New South Wales: Northern Tablelands: MacDonald River, Walcha Road, May A1004, Jan 1970 (NSW).

\section{Nostocales: Rivulariaceae}

\section{Rivularia (Roth) C. Agardh ex Bornet \& Flahault}

Four species previously reported from Australia (Day et al. 1995; Entwisle \& Nairn 1999) with a large number of species worldwide. Rivularia natans of Playfair (1917) is now Gloeotrichia natans (Hedw.) Rabenhorst (see Day et al. 1995); R. borialis P.G. Richt. and $R$. calcarea $\mathrm{Sm}$. are reported without sufficient documentation to verify, and there were no voucher materials available for study.

\section{Key to species of Rivularia}

1 Colony tough, usually stony; trichomes in concentric zones 3a. R. concentrica

$1 *$ Colonies soft or rubbery, not stony; trichomes variously aligned, not in concentric zones .. 2

2 Trichomes 8.5-9.5 $\mu \mathrm{m}$ wide at base, tapering to a narrow hair ..... 3b. R. aquatica

2* Trichomes no more than $6.0 \mu \mathrm{m}$ wide, tapering into a broad hair 3c. R. beccariana

\section{3a. Rivularia concentrica Skinner E Entwisle sp. nov.}

Rivularie haematites (DC) C. Agardh aut R. rufescenti Nägeli similis sed sine calcificatione, vaginis hyalinis aut fulvis in fasces atque cellulis cylindricis, 3.6-4.8 $\mu \mathrm{m}$ diametro, heterocytibusque late sphericis, 6.0-7.2 $\mu \mathrm{m}$ diametro.

Holotype: Tasmania: Bronte Park, tributary of Pine River, Pine Tier Road, before Pine Tier dam turnoff, Entwisle 2599, 9 Apr 1996 (MEL 2033594). Isotype NSW.

Colony firm, dense, domed to globular, 2-6 mm high, encrusting, banded internally with two or more concentric layers at false branching points. Sheaths visible, laminated and often tinted yellow or brown; primary sheath frequently with several secondary sheaths resulting from false branching; trichomes long, radiating, frequently helically spiralled, without much taper; cell closest to the heterocyte distinctly domed and sometimes pointed, other cells cylindrical, one to several times longer than broad, 3.6-4.8(-6.0) $\mu \mathrm{m}$ diam., often with a long hair-like end of cylindrical cells with less dense cytoplasm; basal trichome continuing growth after false branching, may have its terminal section extended to the outer margin of the thallus; cells in newly developed trichomes in regions of false branching distinctly broader in the meristematic region behind the heterocyte; heterocytes broadly spherical, diam. 6.0-7.2 $\mu \mathrm{m}$, separated from the vegetative cells, occasionally in pairs, triples or fours in which case the lower one(s) may be more conical or hemispherical than spherical, sometimes subtended by one to a series of calypterae. Hormogonia of four to twelve or more short $(\mathrm{L} / \mathrm{D}<1)$ 
slightly inflated cells in own sheaths developing at external ends of trichome tubes. (Fig. 2 a-e).

Etymology: the specific epithet concentrica (L) refers to the concentric zones of false branching which gives a banded appearance to the hemispherical colonies under the microscope even at low magnification.

Diagnostic features: heterocytes large (6.0-7.2 $\mu \mathrm{m}$ diam.), spherical and widely separated from the trichome; mature trichome cells cylindrical, narrow, 3.6-4.8 $\mu \mathrm{m}$ diam., without any great change in size throughout length of trichome; 'sheaths inside sheaths' structure of the thallus; and the absence of lime accumulation, make this species distinct from other concentric branching species, such as $R$. haematites and R. rufescens.

Distribution and ecology: this taxon grows along the margins of fast-flowing waterways, and on the stones and pebbles in the stream bed. The disjunct distribution, Tasmania and southern New South Wales only, presumably reflects the paucity of collections.

Notes: the specimens examined key to a pair of taxa in Bornet \& Flahault (1888), $R$. rufescens Naegeli and R. haematites (DC) C. Agardh, but differ in several ways. Like those species, $R$. concentrica shows concentric zones of development, and hair-like tapered ends of some trichomes, as mentioned in Bornet \& Flahault (1888).

The manner in which several sheaths may be grouped inside a primary sheath (which appears to be in Fibonacci series) is distinctive for $R$. concentrica. Trichomes in $R$. haematites (Ex sicc. 331) appear to be grouped but without the retention of an outer primary sheath. There is some retention of the outer sheath in R. rufescens (Ex sicc. 332) involving three or fewer trichomes.

The recently formed trichomes in $R$ concentrica show a region of broad short cells towards the heterocyte, but the mature trichome has more or less even cylindrical cells until the hair region is reached. There is a gradual shortening in cell size towards the hair described for $R$. haematites, and those in $R$. rufescens are described as subquadrate and almost equi-dimensional.

Bornet and Flahault (1888) indicate that they viewed De Condolle's specimen of $R$. haematites, which was part of Thuret's herbarium. This is presumably the type for R. haematites. Geitler (1932) cites both Stockmayer 331 (for R. haematites) and Stockmayer 332 (for R. rufescens) as reliable ex siccatae.

The nature and function of the proliferations, trichomes which appear wound up on themselves inside their sheath, with some cells replaced by prismatically dense material which may occur in straight trichomes also, has not been established (no living material has been examined by the authors). They may, like similar structures in Nostoc species, function as gemmae if the colony collapses or is damaged by external forces. The Australian material, while firm and stony, did not show lime encrustation. $R$. concentrica is probably a much more common and widespread species than present records indicate.

Further specimens examined: New South Wales: South Coast: Pambula R, Chalkhills Rd, off Wyndham-Pambula Rd, 8 km WNW of Pambula, Entwisle 1856, 5 Feb 1991 (MEL); Wallagaraugh $\mathrm{R}$, Newtons Crossing, picnic area, Allan Brooke Rd, $5 \mathrm{~km} \mathrm{~S}$ of Rockton-Eden Rd, Entwisle 1849, 4 Feb 1991 (MEL).

Tasmania: Adams R, above Adams Falls at confluence of two streams, Adams Bay, Lake Gordon, off Strathgordon Rd, c. 22 km ENE of Strathgordon, Entwisle 2604, 9 Apr 1996 (MEL); Lisdillon Rivulet, Orford-Swansea rd, 20 km from Swansea, Entwisle 2611, 11 Apr 1996 (MEL).

Comparative specimens examined: Rivularia haematites, river gorge at Weissenbach, near Frankenfels, Austria, Stockmayer 331, Krypt. exsicc. Mus. Pal. Vindobon. (NSW); Rivularia rufescens, 

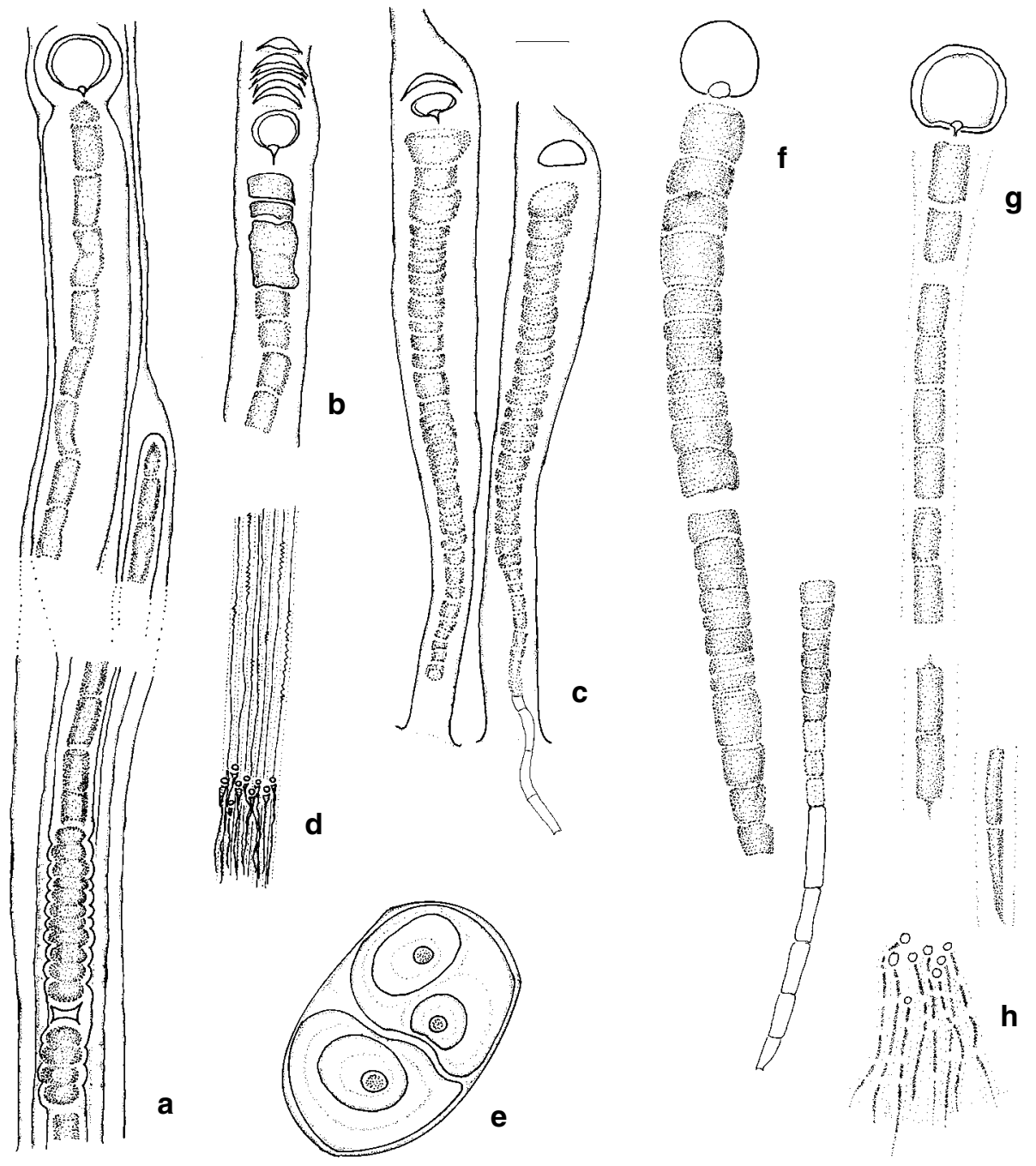

Fig. 2. Rivulariaceae: a-e, Rivularia concentrica, a, Mature trichomes, showing concentric sheaths and hormogonia; $\mathbf{b}$, Multicalypterate developing trichome; $\mathbf{c}$, Two developing trichomes, one with hair; d, pattern of false branching zone; e, cross-section of fascicle of sheaths (Entwisle 2599); $\mathbf{f}, R$. aquatica, trichome (Entwisle 2244); $\mathbf{g}-\mathbf{h}, R$. beccariana, $\mathbf{g}$, trichome; h, radiating pattern of trichomes (Coveny 18642). Scale bar $=10 \mu \mathrm{m} ; \mathrm{d}$, h not to scale. 
river gorge at Weissenbach near Frankenfels, Austria, Stockmayer 332, Krypt. exsicc. Mus. Pal. Vindobon. (NSW).

3b. Rivularia aquatica De Wild., Prodr. fl. algol. Ind. néerl., suppl. 1: S 40 (1897).

Colonies soft gelatinous to c. $1 \mathrm{~cm}$ across, brown-green to green. Trichomes free in the matrix; sheath not easily visible, taper gradual then abrupt to form a long hair; cells subspherical, L/D 0.75-1.25, 9.6-8.4 (to $6.0 \mu \mathrm{m}$ before hair) diam., hair cells cylindrical

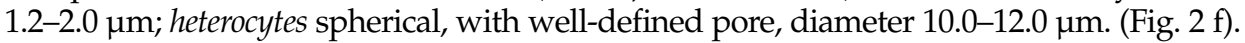

Distribution and ecology: widespread, eastern tropical areas. Only found once in Australia as soft jelly-like colonies on cobblestones in the bed of a broad, shallow meandering stream.

Notes: the single collection closely matches the description of $R$. aquatica in Desikachary (1959). This has the largest cellular and trichome dimensions of the three species described here.

Specimen examined: Queensland: Cattle Creek, Mackay-Eungella Road, $1 \mathrm{~km} \mathrm{~W}$ of Gargett, Entwisle 2244, 8 Sep 1993 (MEL).

3c. Rivularia beccariana De Notaris ex Bornet \& Flahault, Ann. Sci. Nat. Bot., 7s, 4: 356 (1886).

Colonies to $1 \mathrm{~cm}$ in diameter, gelatinous to rubbery, green to brown-green or bluegreen. Trichomes radiating, no distinct layering, tapering gradually into hair; cells cylindrical,(8.0-)12.0-18.0 $\mu \mathrm{m}$ or more long, (3.6-)4.8-6.0 $\mu \mathrm{m}$ diam.; cells in hair 2.4-3.6 $\mu \mathrm{m}$; basal heterocyte spherical, 7.2-8.4 $\mu \mathrm{m}$ diam. (Fig. $2 \mathrm{~g}-\mathrm{h}$ ).

Distribution and ecology: $R$. beccariana has been recorded from Queensland also (McLeod 1975) and in various other parts of the world. $R$. beccariana is an epiphyte on aquatic vegetation, especially Characeae in Australia, or may be found attached to tree-roots or rock, usually in slow-flowing streams, submerged or in splash zones. It is likely that this taxon may be found in many localities where stoneworts occur throughout the continent.

Notes: fits the description given in Desikachary (1959, p. 551) well. This species is probably overlooked in collections of aquatic plants, and is likely to be widespread.

Specimens examined: New South Wales: Northern Tablelands: Severn R., Dundee, on Vallisneria, Skinner 0082, 22 May 2000 (NSW). Central Coast: Dismal Swamp, Wollemi National Park, on Myriophyllum leaves, Coveny 18642, 4 Sept 2000 (NSW).

Victoria: Dandenong area, Devilbend Reservoir, south of Mornington, Mackey A \& B, 19 Mar 1991 (MEL 2028556 and 2047042).

Northern Territory: Nitmiluk National Park, Seventeen Mile Ck, near crossing on track from Katherine Gorge to Edith Falls (c. 1 hour along track), Entwisle 2714, 2715 \& 2716, 2 Jun 1997 (MEL).

4. Gloeotrichia J. Agardh ex Bornet \& Flahault

A genus of numerous species, throughout the world. In Australia three freshwater species have been reported previously (Day et al. 1995; Entwisle \& Nairn 1999); here is a fourth.

Gloeotrichia pilgeri Schmidle, Hedwigia 40: 54 (1901).

Colonies microscopic tufts on aquatic plants or among rafts of other algae, with a small number (c. 12) of radiating trichomes. Trichome long, especially the hair. cells short and closely packed, 3.6-10.8 $\mu \mathrm{m}$ diam; hair cells cylindrical, L/D 2.5-3, 3.6 $\mu \mathrm{m}$ diam.; sheath clear, not laminated, reaching at least as far as the start of the hair; heterocytes spherical, singly or in pairs at base of trichome, and intercalary above the akinete, 7.2-8.4 $\mu \mathrm{m}$ diam.; akinete cylindrical to reniforme, 28-36(40) $\mu \mathrm{m}$ long, 14-16 $\mu \mathrm{m}$ diam. (Fig. $3 \mathrm{a}-\mathrm{c}$ ). 
Distribution and ecology: widespread outside Australia in tropical areas. Growing with Cylindrospermum as film on mud or vegetation.

Notes: this collection contains a small number of plants that match the description of G. pilgeri in Desikachary (1959, p. 558) and Geitler (1932).

Specimen examined: Northern Territory: Fish Hole, SW of Daly River settlement, Ross 3784, 12 Sept 1996 (MEL).

There is an herbarium specimen in MEL of Gloeotrichia from South West National Park, Tasmania (in the creek from Harrys Bluff into Old R., c. $1 \mathrm{~km} \mathrm{~N}$ of Harrys Bluff, at confluence of two streams (Entwisle 2541, MEL)) but with insufficient material to determine the specific identity. A specimen in NSW collected by Sainty (NSWA 3183) is labelled as the 'Gloeotrichia natans Rabinh. ex Bornet \& Flahault ecophene of Calothrix parietina (Nägeli) Thuret according to Drouet' but has no locality, date or field notes. It was probably collected in the rice growing area around Griffith, N.S.W. It certainly fits descriptions of $G$. natans. Other material was not available to us.

\section{Dichothrix Zanardini}

A genus with a small number of species worldwide and one species previously recorded from Australia (Day et al. 1995; Entwisle \& Nairn 1999). D. baueriana Grunow is listed for the Barron River in Queensland by Borge (1911) and included in Bailey's (1913) census; no further data are available. McLeod (1976) gives a clear description and illustration for D. baueriana from the St Lucia ferry landing, on the Brisbane River. No material matching that taxon has been examined in the current study.

Dichothrix gypsophila Kützing ex Bornet \& Flahault, Ann. Sci. Nat., Bot., sér. 7, 3: 377 (1886).

Colonies forming spreading, furry, gelatinous flakes, green-black, about $1 \mathrm{~mm}$ high. Thallus spreading from a basal knot of subdichotomous branching. Filaments of partly confluent tapering trichomes, 9.0-13(-15) $\mu \mathrm{m}$ diam., in moderately wide yellowish divaricate sheath systems; trichomes slightly inflated immediately above the basal heterocyte, then tapering gradually to a domed terminal cell or a short hair; cells cylindrical, L/D 0.5-1, 4.0-9.0 $\mu \mathrm{m}$ diam.; hair cells c. $4.0 \mu \mathrm{m}$ diam., $6.0 \mu \mathrm{m}$ long; heterocytes basal, usually solitary, hemispherical, c. $6.0 \mu \mathrm{m}$ long, 9.0-12.0 $\mu \mathrm{m}$ diam.; false branching at heterocytes or lateral to trichome, lower trichome diverging quickly, each trichome in its own sheath system; sheath system an imbricate series of sleeves, each with a short funnel-like end, basal ones yellowish, apical ones more hyaline, 6.0-15 $\mu \mathrm{m}$ diam., enclosing the whole trichome, including the hair. Hormogonia straight, torulose, equivalent to two, four or many more cells, narrower than cells, darker pigmented and grainy, to $50 \mu \mathrm{m}$ long, c. $4.0 \mu \mathrm{m}$ diam., formed in apical section of filament branches. (Fig. $3 \mathrm{~d} \& \mathrm{e}$ ).

Distribution \& ecology: cosmopolitan. Known from the Hawkesbury Sandstone area in Australia, where it occurs in the splash zones of seasonal creeks and waterfalls, and on the flagstones around fountains.

Notes: our specimens of somewhat gelatinous green-black flakes match closely Dichothrix gypsophila (Kütz.) Bornet \& Flahault. They have partly confluent tapering trichomes in sub-dichotomously false branching filaments with flared sheaths. Our material shows less of the divarications of sheath illustrated by Geitler (1932) but otherwise fits the description.

Dichothrix gypsophila has sometimes been referred to Calothrix (see Desikachary 1959, $\mathrm{p}$ 545). As the branches are confluent at least to begin with, and there is a divergence of the branches but not a complete separation, giving something of a penicillate appearance to the thallus, this taxon appears to fit best in Dichothrix as circumscribed 


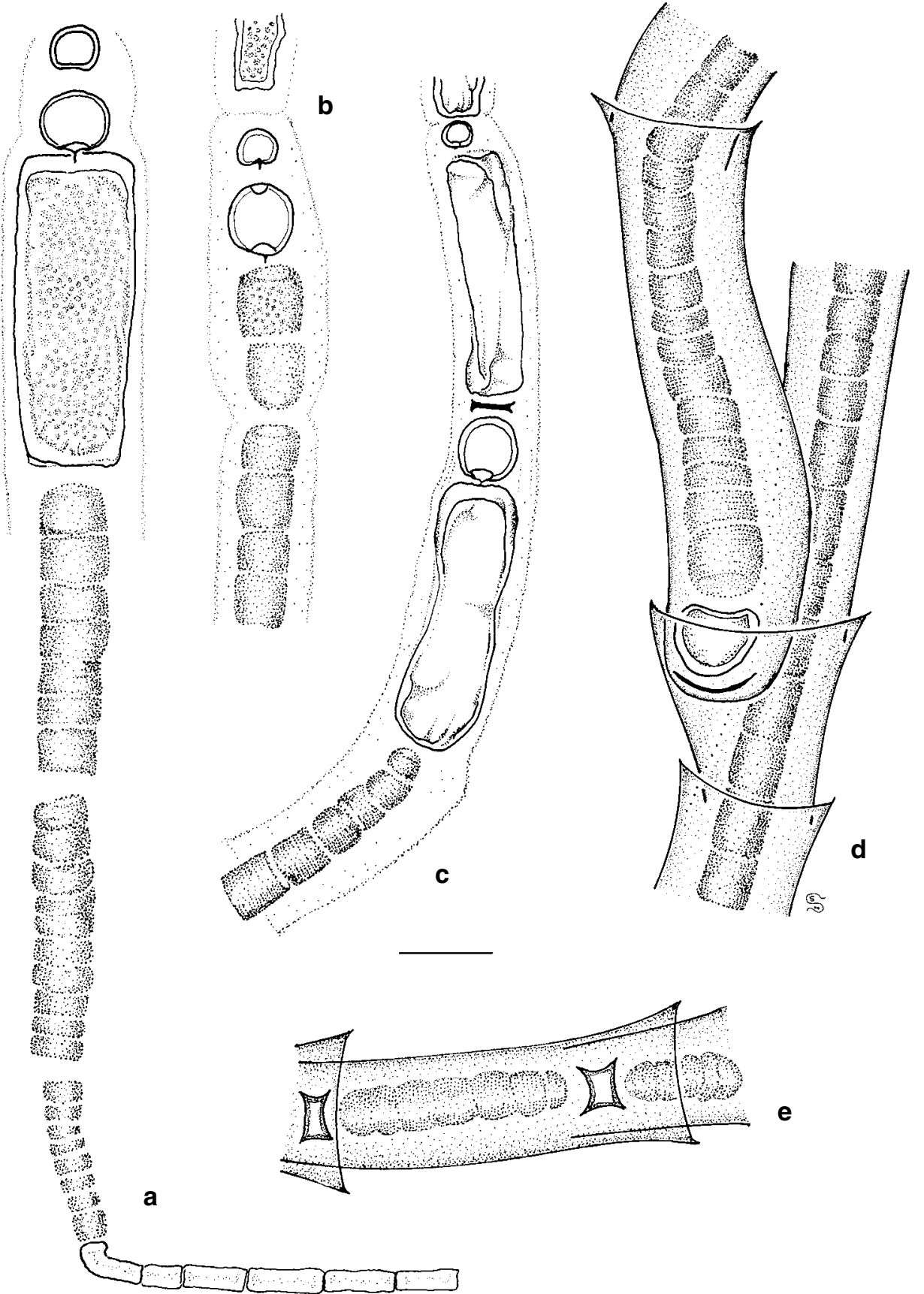

Fig. 3. Rivulariaceae: a-c, Gloeotrichia pilgeri, trichomes with various combinations of heterocytes and akinetes (Ross 3784); d-e, Dichothrix gypsophila, d, branching pattern, e, hormogonia (Skinner 0047). Scale bar $=10 \mu \mathrm{m}$. 
in Komárek \& Anagnostidis (1989). Our specimens lack distinct basal bulbs, and so, while the dimensions would be close, do not fit in D. hosfordii (Wolle) Bornet, and the presence of the distinctive funnel-like sheath ends separates them from D. baueriana, which has its sheath ends closed over.

Specimens examined: New South Wales: Central Coast: Royal Botanic Gardens Sydney, Skinner 0047, 17 Mar 2000 (NSW); Falls Picnic Area track, Manly Warringah War Memorial Park, Curl Curl Ck, Allambie Heights, Entwisle 2913, 26 Dec 1998 (NSW).

\section{Nostocales: Nostocaceae}

\section{Cylindrospermum Kützing ex Bornet \& Flahault}

Eleven taxa have been reported from Australia (Day et al. 1995; Entwisle \& Nairn 1999). The genus is a large one, and common in freshwater throughout the world although most are not conspicuous in the field and so may qualify better as microalgae. Some material was not available to us during our investigation. The current status of some of Playfair's taxa is discussed below, under C. stagnale Kütz.

Prescott (1951) notes that C. licheniforme Kütz. forms patches of 'macroscopic proportions' on soil and aquatic vegetation, as does the type species, C. stagnale. Komárek (1989) discusses problems arising in the delimitation of species in this genus from inconsistencies in descriptions and iconotypes especially in older literature. As his cyclogram approach depends on statistics from numerous collections it has not been followed here but our descriptions are based on his list of characters.

\section{Key to the species of Cylindrospermum}

1 Akinetes distinctly ellipsoidal at maturity 6a. C. licheniforme

$1^{*}$ Akinetes mostly cylindrical at maturity 6b. C. stagnale

6a. Cylindrospermum licheniforme Kützing ex Bornet \& Flahault, Ann. Sci. Nat., Bot., sér. 7, 7: 253 (1888).

Colony forming conspicuous cumulous patches. Trichomes long, somewhat intertwined and fragmenting; vegetative cells uniformly cylindrical, L/D 1-2.5, 4.0-5.0 $\mathrm{mm}$ diam.; heterocytes terminal, cylindrical to ovate, with an outer envelope and a prominent pore connecting to the next cell, 10.0-12.0 $\mu \mathrm{m}$ long, $5.0 \mu \mathrm{m}$ diam.; akinetes developing directly behind the heterocyte, ellipsoid, smooth, clear walled, 26-36 $\mu \mathrm{m}$ long, 14.0-16.0 $\mu \mathrm{m}$ diam. (Fig. 4 a, b).

Distribution and ecology: cosmopolitan, this taxon has been recorded previously from Queensland (Baker \& Fabbro 1999). It can be found attached to mud or vegetation in streams or puddles.

Notes: Although the cells may be broader than those described by Desikachary (1959), the specimen fits comfortably within C. licheniforme as circumscribed by that author and Prescott (1951).

Specimens examined: New South Wales: North Coast: Paterson R., Pound Crossing Bridge, Singleton-Gresford Rd, 2 km SW of Gresford, Entwisle 1939, 8 Feb1991 (MEL).

6b. Cylindrospermum stagnale Kützing ex Bornet and Flahault, Ann. Sci. Na.,. Bot., sér. 7 , 7: 250 (1888).

C. rectangulare Playfair Proc. Linn. Soc. NSW 43: 506 (1918); C. goetzei Schmidle forma Playfair, loc. cit.: 507 (1918). 
Colonies either filmlike on mud and marginal vegetation, or substantial gelatinous cumulous masses, bright bluish green to greyish green. Trichomes long, parallel or intermingling, both ends terminating in a heterocyte; cells cylindrical, similar in size throughout the trichome, granular bluish green, L/D (0.8-)1-2(-2.5), 3.6-4.8 $\mu \mathrm{m}$ diam.; sheath faint; heterocytes variable, sub-conical to domed cylindrical, terminal, and either or both may be subtended by an akinete, prismatically dense, (4.8-)6.0-9.6 $\mu \mathrm{m}$ long, 4.8-6.5 $\mu \mathrm{m}$ diam.; akinetes prominent, variable in occurrence, smooth walled, slightly yellow staining, cylindrical to slightly inflated in the same group of trichomes, (22-)24-27 $\mu \mathrm{m}$ long, (8.4-)9.6-12 $\mu \mathrm{m}$ diam. Possible hormogonia 4-, 6- or 8-celled packets, similar to vegetative cells. (Fig. 4 c).

Distribution and ecology: widespread and common in most parts of the world. In Australia reported from the Northern Territory, Queensland and New South Wales. The two recent specimens examined here are from more temperate areas than previously reported in New South Wales. The collections were made along cold water streams in alkaline soil agricultural land, as rafts of scum either at the margins of pools or stranded on the banks.

Notes: separation of $C$. licheniforme and C. stagnale is made on the shape of the mature akinete (Geitler 1932), which in the case of C. licheniforme is described as consistently ellipsoid, while that of $C$. stagnale can range from cylindrical to somewhat inflated. The akinetes in Entwisle 1939 are consistently ellipsoid and usually longer than those of Skinner 0157, which are consistently cylindrical. Mature akinetes are less frequent in Skinner 0199, but range from cylindrical to inflated, rather like the range for which Playfair (1918) describes different forms and even species in his Lismore material.

Playfair described C. rectangulare from Lismore in northern NSW. The Type material, in Bottle No. 256 (Lismore, dripping rocks halfway up New Cut, 6 Sept 1915) complements Playfair's description closely. A further three collections cited by Playfair $(1915,1918)$ have dried out and did not respond well to rehydration. Bottle No. 270 (WoyWoy, Lucas, Oct 1915) is said by Playfair to contain the variant form, var. parvicellula Playfair (1918) but the material failed to rehydrate. All four bottles mentioned were sent to Drouet in 1975, and returned, on his death, in 1983. No correspondence from Drouet, describing his findings, has been located at NSW.

C. rectangulare shows close similarities to $C$. stagnale, but has a dolioform to elliptical (16-22(-38) $\mu \mathrm{m} \times 7-10(-14) \mu \mathrm{m}$ (Playfair 1915, 1918)) mature akinete. Playfair's (1918) opinion, "they are merely allotropic forms of one plant," is further indication of the need for a revision in the light of modern work. It is worth noting that specimens of C. stagnale described by Scott \& Prescott (1958) from Arnhem Land in the Northern Territory have akinetes of similar dimensions to those given by Playfair. The opinion of the present authors is that all the taxa described by Playfair (1918) probably fit into C. stagnale, and that separation of C. licheniforme from C. stagnale may prove to be unsustainable if more were known about the range of variability in the genus.

Specimens examined: New South Wales: North Coast: Lismore, the New Cut [probably the New Ballina Cutting], Playfair 256, 6 Sept 1915 (NSW); Deer Park R., Waterfall Way, W Cherry (Skinner 0157), 24 May 2000 (NSW); Northern Tablelands: Bergen op Zoom Creek, 8km N of Walcha, Skinner 0199, 25 May 2000 (NSW).

A species of Cylindrospermum was also present with the collection of Gloeotrichia pilgeri (Ross 3784). While there were akinetes present, they were infrequent and immature, and the material has been provisionally assigned to Cylindrospermum sp. aff. catenatum Ralfs ex Bornet and Flahault (Fig. 4 d, e). Specimens of taxa referable to this or allied genera are often encountered in samples of rafts of freshwater algae or other aquatic plants in Australian collections but may be overlooked because of greater interest in the other material. 


\section{Nostoc Vaucher ex Bornet \& Flahault}

There have been fifteen species names associated with records of Nostoc in Australia (Entwisle \& Nairn 1999), mostly in species lists, with few detailed descriptions, and the genus has not been revised for the continent. The present treatment is based on those collections available to us, and covers those taxa we accept as macroalgae.

Nostoc is commonly found in permanent freshwater, in temporary waterbodies, and on soil, even in arid areas, but is infrequently collected. Nostoc has been reported from saline wetlands in Australia (Brock 1986: 133), but without convincing evidence that it was metabolically active in such environments.

Modern approaches to Nostoc taxonomy involve much information beyond that used for conventional morphological classification (Mollenhauer et al. 1994). While acknowledging the validity of such approaches, especially in countries where there are one hundred and fifty years or more of research history and specialized facilities close at hand, we are aiming here to establish a baseline for Australia from which field and laboratory work can start. If a name applied is an hypothesis that allows challenge,

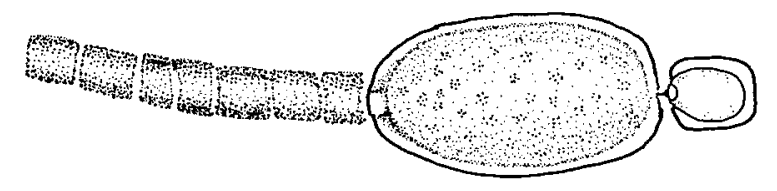

a
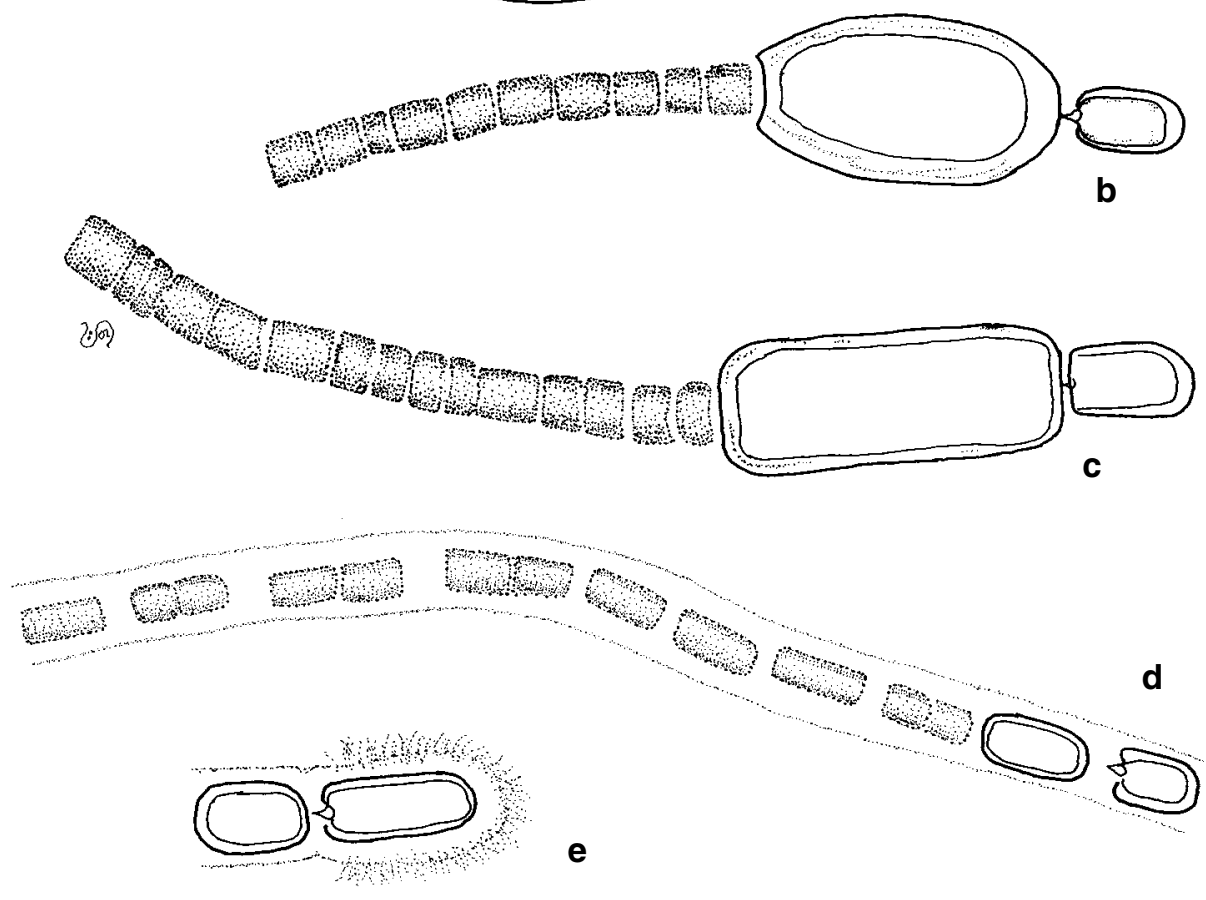

Fig. 4. Nostocaceae: $\mathbf{a}, \mathbf{b}$ Cylindrospermum licheniforme, $\mathbf{a}$, developing akinete; $\mathbf{b}$, mature akinete (Entwisle 1939); c, C. stagnale, mature akinete (Skinner 0157); d, e C. sp. aff. catenatum, d, trichome; e, mature heterocyte and akinete (Ross 3784). Scale bar $=10 \mu \mathrm{m}$. 
then we feel justified in putting forward a name, with a description and authorities, in order to have that name and circumscription challenged.

Hormogonia fitting the classical criteria re-emphasised by Mollenhauer et al. (1994) have been encountered rarely in our material (e.g. Cherry 336, 337). Proliferations, or budding of whole colonies, have been encountered in N. commune (e.g. Savage, 4 Oct 2000) and may have been overlooked elsewhere. Frequently, Australian material has shown contracted trichomes in thickened, and often solidified, sheaths in the surface of mature colonies (see N. flagelliforme, N. commune and N. pruniforme). Given the dramatic fluctuations in climatic conditions on this continent, these resting stages may be a regional variant on the thin-walled, clear bag-like hormogonia, which are able to glide off from the parent colony in favourable conditions.

\section{Key to species of Nostoc}

1 Colonies thread-like, or firm but loosely saccate to spreading, surface smooth or wrinkled, not warty; often terrestrial 2

$1^{*}$ Colonies spreading and warty or a fused mass of globules or individual globules, or soft and fluid; mostly aquatic 4

2 Colonies thread-like; trichomes long and more or less parallel, in the direction of the thread 7a. Nostoc flagelliforme

$2 *$ Colonies saccate to spreading; trichomes variously arranged in the matrix of the colony ... 3

3 Trichomes short and determinate, of 12 or less cells, scattered through the matrix; aquatic or semi-terrestrial $7 \mathrm{~b}$. N. borzioides

$3^{*}$ Trichomes longer and indeterminate, often more crowded towards the outside of the colony; usually terrestrial

7c. N. commune

4 Colony encrusting, often deflated, when wet velvety and cloth-like, hard to squeeze apart; trichomes of barrel-like cells, about half the diameter of the heterocytes; proliferating propagules absent; akinetes smooth-walled, ovate

7d. N. verrucosum

$4^{*}$ Colonies spherical or globular (especially when small, tough and rubbery) or fluid, gel-like and easily broken, separating and returning if squeezed; trichomes of subglobose, ellipsoid or cylindrical cells similar in dimensions to heterocytes; proliferating propagules sometimes present; akinetes ellipsoid to cylindrical, smooth or spiniferous 5

5 Akinetes smooth-walled, oval to elliptical; cells spherical to ovate, similar to heterocytes; hormogonia spiraled in sacs, with heterocytes at one or both ends 7e. N. pruniforme

$5^{*}$ Akinetes spinose, cylindrical to reniform; cells ovate to cylindrical, similar to intercalary heterocytes only; hormogonia not seen

7f. N. gelatinosum

7a. Nostoc flagelliforme Berkley \& Curtis, Intro. Cryptog. Bot. 142 (1857).

Nostoc commune var. flagelliforme Berkeley \& Curtis ex Bornet \& Flahault, Ann. Sci. Nat. Bot., sér. 7, 7: 206 (1888).

Colony an intertwined collection of fine, slightly lacunate tubes, greenish brown when moist, drying black. Trichomes arranged parallel to the long axis of the tube, straight to slightly wavy; cells subglobose to dolioform, (3.5-)4.0-6.0 $\mu \mathrm{m}$ diameter; heterocyte intercalary or falsely terminal, not frequent, ovate, $6.0 \mu \mathrm{m}$ long, $8.5 \mu \mathrm{m}$ diam.; akinetes in series of 2, 4 or 6, thick walled, similar in dimensions to vegetative cells. Hormogonia with or without heterocytes, tightly coiled mass of four to twenty cells in sheath, becoming hardened into small pustules on the thallus surface (Fig. $5 \mathrm{a}-\mathrm{c}$ ). 
Distribution and ecology: a dryland species, found in Australia in saltbush steppe, on bare ground, solonized brown calcareous soil, with pebbles of quartz and ironstone. Also found in western China, south-western United States of America, Namibia and other arid areas.

Common name: Facai (Fat tsai) (Lembi \& Waaland 1988, Gao 1998). It is sold commercially as food in New South Wales as Black Moss.

Notes: this species, sometimes treated as a variety of $N$. commune, is recorded from arid parts of many countries. Gao (1998) presents a summary of recent research, describing, among other things, the effect of wild harvesting on quality, and some suggestions for cultivation. Gao (1998) mentions studies that have shown that flattening of the thallus may occur on soils with relatively high moisture content. The broader, buried ends are not visible in our Yunta specimen (NSW A3124), but the environmental conditions described for Chinese plants are close to those of the shrub steppe near Yunta. In other microscopic and macroscopic details NSW A3124 is similar to the commercial specimen and published descriptions. The Mereenie specimen ( Latz 17364) is similar, but does show some broadening of tubes on contact with the soil, and occasional forking of tubes. The trichomes in Latz 17346 are pronouncedly in rows, as in the commercial specimen, the vegetative cells are subglobose, there are frequent series of akinetes and occasional hormogones.

The Western Australian specimen (Bratt 67/250) had been assigned in HO to Wollea saccata (Wolle) Bornet \& Flahault, but is generally slightly smaller in cell dimensions than Prescott's (1951) description and lacked the characteristic large akinetes of $W$. saccata. Bratt $67 / 250$ is probably best placed in $N$. flagelliforme although the colonies are wider and flatter than the Yunta or Mereenie specimens or commercial $N$. flagelliforme, but agree in other respects. It should be noted that it was found in association with $N$. commune which may indicate stability of the morphological forms in harsh habitats, and so support separation of these taxa as two distinct entities. The presence of hormogonia with thickened sheaths may also be an indication of response to the arid habit of this specimen.

Specimens examined: South Australia: $3 \mathrm{~km}$ ENE of Panaramitee homestead, 13km SE of Yunta, Lowe, 16 Nov 1979 (NSW A3124).

Western Australia: Eyre Highway, 110 km W of Caiguna Tank, Bratt 67/250, 6 Oct 1967 (HO).

Northern Territory: Mereenie, 1 km NE of Eastern Satellite Stn, Latz 17364, 23 Nov 2000 (NT, NSW). Cultivated commercial specimen (Skinner 0053, 23 Mar 2000) purchased in an Asian grocery in Ashfield, NSW.

\section{7b. Nostoc borzioides Skinner \& Entwisle, sp. nov.}

Thallus gelatinosus lamellaris vel plicatus vel laciniatus cuius trichomata determinata Borziae triloculari similia, cellularibus usque ad duodecim inclusis heterocytibus aut terminalibus aut intercalaribus.

Holotype: Northern Territory: Gregory National Park, Limestone Gorge, c. 8 km NNW of Bullita outstation, Latz [Duretto 1117], 16 April 1996 (MEL). Isotype: NSW.

Colony irregularly shaped, often elongate and tattered, rubbery, blue-green, mostly $2-4 \mathrm{~cm}$ long; trichomes arranged irregularly, 16-24 $\mu \mathrm{m}$ long, of 3-6(-12) cells; cells 3-4(-5 when dividing) $\mu \mathrm{m}$ long, 4-6 $\mu \mathrm{m}$ diam., terminal cells semi-globose; intercalary cells disc- to barrel-shaped; heterocytes spherical to depressed globose, terminal or intercalary, singly or more rarely in pairs, sometime absent, similar in size to vegetative cells or a little smaller, with pore at either end (if intercalary); individual sheaths not visible in the gel in this specimen; akinetes or propagules not seen. (Fig. $5 \mathrm{~d}-\mathrm{f}$ ). 

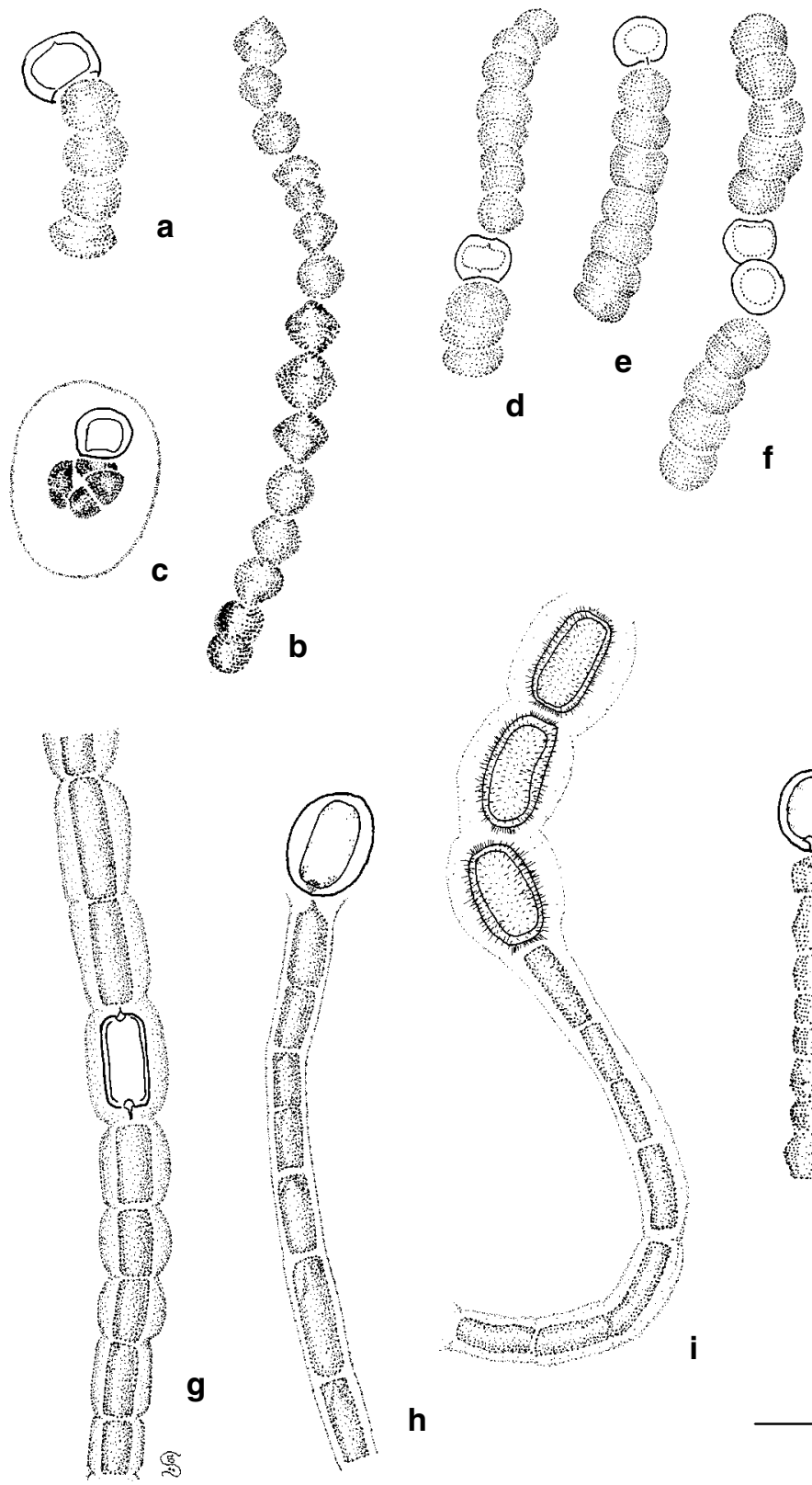

h
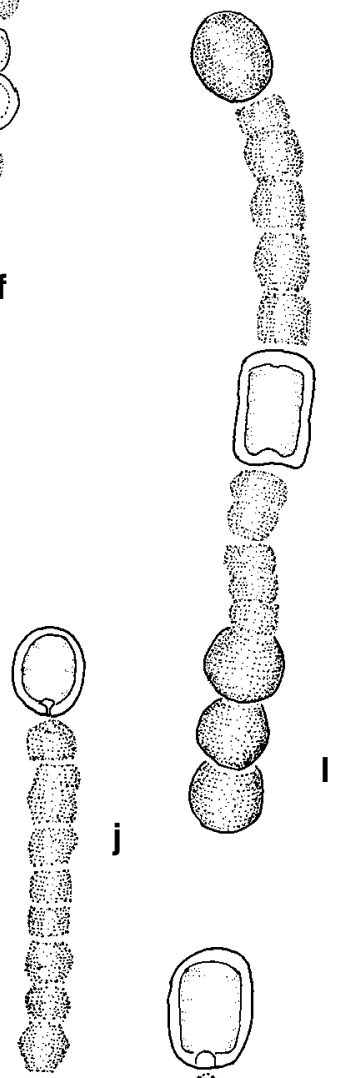

(a)

旅

t?

क्ष

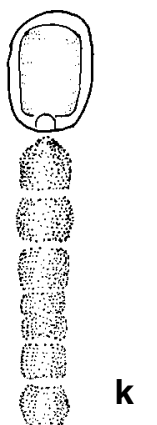

Fig. 5. Nostocaceae: a-c Nostoc flagelliforme $\mathbf{a}$, trichome with terminal heterocyte; $\mathbf{b}$, part of trichome; c, hormogonium (NSWA3142); d-f, Nostoc borzioides, determinate trichomes with heterocytes (Duretto 1117); $\mathbf{g}-\mathbf{i}$, Nostoc gelatinosum $\mathbf{g}$, trichome with intercalary heterocyte; $\mathbf{h}$, terminal heterocyte; $\mathbf{i}$, series of akinetes (Skinner 0178); $\mathbf{j}-\mathbf{1}, \mathbf{N}$. verrucosum, $\mathbf{j}$, $\mathbf{k}$ trichomes with terminal heterocytes; 1 , trichome with intercalary heterocyte and akinetes (Skinner 0057). Scale bar $=10 \mu \mathrm{m}$. 
Etymology: the species epithet is from Borzia, a genus in the Oscillatoriales to which the short trichomes of this species of Nostoc can be compared, especially when heterocytes are absent or rare.

Distribution and ecology: known only from the type locality where growing in a small drying rockpool on limestone.

Diagnostic features: similar to Borzia trilocularis in trichome morphology, but such trichomes, often with terminal or intercalary heterocytes, always in a rubbery thallus characteristic of Nostoc. Nostoc species generally have trichomes with at least twenty cells, and are rarely as consistently determinate in cell numbers as this taxon.

Notes: while we are reluctant to add a new species to the already cluttered cyanobacterial literature based on a single preserved collection, the short determinate trichomes are very distinctive. As soon as fresh material comes to hand we will endeavour to have its genetic affinities resolved.

7c. Nostoc commune (L.) Vaucher ex Bornet \& Flahault, Ann. Sci. Nat. Bot., sér.7, 7:203 (1888).

Colony globose to laminate, rubbery, variously green, yellowish green, blue-green or blackish, solid but more frequently hollow, from a few $\mathrm{mm}$ to several $\mathrm{cm}$ across; trichomes usually not closely appressed and evenly distributed, variable in length; sheaths visible in some parts of thalli, wide, convoluted and following the shape of cells and trichome, hyaline or lightly discoloured; cells subglobose to barrel-like, L/D 1-1.5, (3.0-)3.6-5.0(-6.0) $\mu \mathrm{m}$ diam.; heterocytes (falsely) terminal, spherical, with one pore, 6.0-7.0(-8.5) $\mu \mathrm{m}$ diam. or intercalary, of similar dimensions, with two pores; akinetes (if present) similar to vegetative cells, with more dense staining cytoplasm, clear wall, singly or in series. Hormogonia, or small vermiform attached colonies (spiral contraction of a trichome, separation from heterocyte by disintegration of cells between, formation of an enclosing sheath) appear 2 or 3 cells thick, in own sheath, at maturity. (Fig. 6 a-d).

Distribution and ecology: cosmopolitan. In Australia, as elsewhere, grows most frequently on bare soil in disturbed situations but may grow in transient aquatic situations, including waterfalls and seepages, from sea level to mountain areas, areas of high rainfall and arid areas alike. Most specimens of $N$. commune in our collections are of quite extensive sheet-like thalli, either saccate or two-sided but continuous, with a folded but not warty surface, and are usually free on the surface of the soil or superficially buried. The specimen from the far west of NSW (Cherry 302) while being microscopically similar to those from free crusts, formed as an embedded blackish crust in the sand, similar to arid area lichens. The individual thalli were domed to subglobose, imbricate and generally less than a millimetre in diameter. The only microscopic difference between this specimen and others was in the tight-fitting laminated sheaths around trichomes, especially at the surface of thalli. Both of these differences may be responses to the arid environment.

From the localities cited here, it is clear that N. commune is widely distributed in Australia, and has a broad ecological tolerance. Even so, collections are infrequently lodged in herbaria, which may account for some of the apparent gaps in distribution.

Common name: over time $N$. commune has accumulated a range of folk names, including Star Jelly, Troll's Butter, and Snot, some of which it shares with other jellylike simple plants. Snot may be the most appropriate, if not the most appealing, common name. According to Potts (1997) Nostoc derives from the name Nostoch suggested by Paracelsus for this common wasteland and pasture organism, a witty wordplay based on superstitious beliefs of its origin and the look and texture of both 


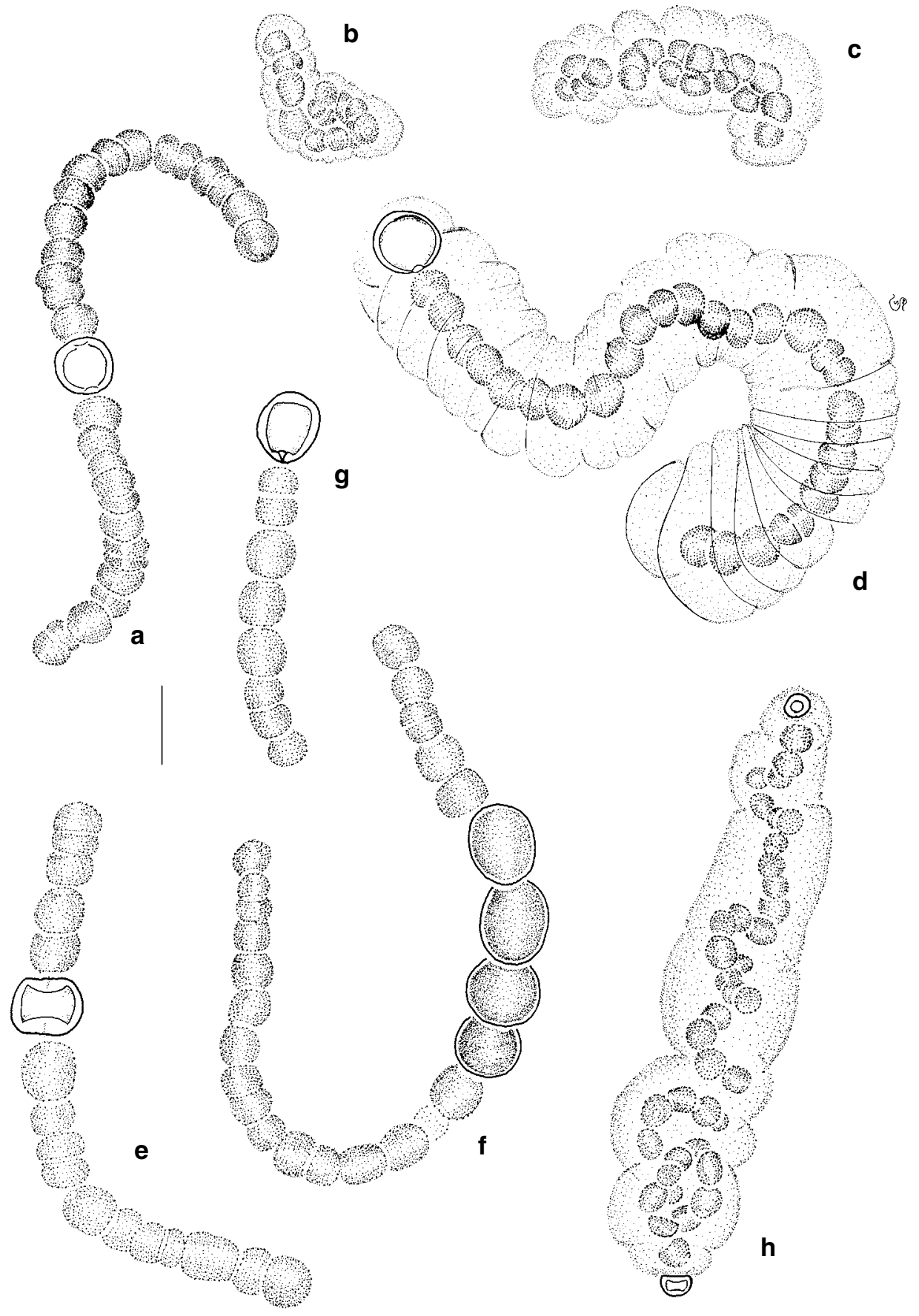

Fig. 6. Nostocaceae: a-d Nostoc commune, a part of trichome with intercalary heterocyte (Coveny 18542); b, c hormogonia (NSW 435426); $\mathbf{d}$ trichome in sheath, from margin of thallus (Coveny 18543); e-h N. pruniforme, e part of trichome with intercalary heterocyte; $\mathbf{f}$ part of trichome with row of akinetes (Skinner 0044); $\mathbf{g}$ terminal heterocyte; $\mathbf{h}$ hormogonium (Entwisle 1862). Scale bar: a, d, e, f, $\mathrm{g}=10 \mu \mathrm{m} ; \mathrm{b}, \mathrm{c}, \mathrm{h}=20 \mu \mathrm{m}$. 
the organism and nasal mucus. Koxianmi (Ge-Xian-Mi) is an ancient chinese name (Lembi \& Waarland 1988; Potts 1997) and as N. commune is sometimes used as a condiment in cooking, especially east-asian cooking, it may have other commercial names in eastern Asia. Llullucha is a name used by the Chinchero people of the Andes, who differentiate between plants collected from different localities in terms of their culinary worth without the aid of scientific instruments (Franquemont et al. 1990).

Notes: a cosmopolitan species, and the one into which Drouet (1978) placed many both colonial and more independent living taxa. We follow current taxonomy and circumscribe it more narrowly. As we have not done any culturing of specimens, we have not had occasion to observe hormogonal mobility. Some specimens, however, have included small attached colonies (or proliferations, see Dodds et al. 1995) in sacks at the margins of thalli.

Prescott (1951) accepts a number of species (e.g. N. commune, N. muscorum C. Agardh, N. linckia (Roth) Bornet \& Flahault, N. verrucosum and N. prunifome) that can be found on soil and in water, where they form as sheets, crusts or globules. These are described as having much similarity in dimensions and form in his description of trichomes, but filling a range of habitats and showing differences in thallus structure and akinete size or form. For instance, N. linckia gets softer with age and has akinetes larger than vegetative cells, and N. muscorum favours soft waters.

Mollenhauer et al. (1999) recommend the distinction of one-pored heterocytes be used to separate $N$. commune from other similar taxa. They also highlight hormogonial development and absence of morphologically distinguishable akinetes as useful characters. The proliferating propagules described in detail for $N$. pruniforme (Mollenhauer 1970) are referred to as hormogones by that author. Similar but distinct structures occur in Australian specimens of N. commune. Australian material assigned to $N$. commune shows one-pored heterocytes in terminal positions, and two-pored intercalary heterocytes in the same specimen. The loose heterocytes are of both forms.

Specimens examined: Queensland: D'Aguilar Range, Northbrook Ck, Mt Glorious-Dundas Rd, Entwisle 2227, 5 Sept 1993 (MEL); Theresa Ck Rd, Milla Milla, Horton s.n., 22 Aug 2000 (NSW).

New South Wales: North Coast: Town Beach, Port Macquarie, Skinner PMC003, 13 Aug 1999 (NSW); Erskine Ck, Lord Howe Island, Kraft [TJE1043], 14 Dec 1986 (MEL); Little Murray River bridge, Waterfall Way, Skinner 0147, 24 May 2000 (NSW); near QLD-NSW border (Warwick-Stanthorpe area), $9 \mathrm{~km}$ by road from Legume to Woodenbong, Oaky Ck, Entwisle 2807, 15 July 1997 (MEL). Central Coast: Uloola Track, Royal National Park, Coveny \& Yee, 28 Nov 1999 (NSW 435425); Blackett, Coveny 18161, 1Jan 2000 (NSW); Cattai, Houghton s.n., 17 Apr 2000 (NSW); Woy Woy, M.Skinner s.n., 17 Apr 2000 (NSW). South Coast: Cobargo, Skinner 0236, 0237, 13 Jul 2000 (NSW); Yowrie, Skinner 0240, 13 Jul 2000 (NSW). Northern Tablelands: Bellevue Oval, UNE, Armidale, Skinner s.n., 11 Dec 1999 (NSW 435426). Central Tablelands: Bundanoon, May s.n., Mar 1967 (NSW); Springwood, O’Neill, 8 May 1979 (NSW A 3126); Honour Avenue, Lawson, Coveny 18542, 26 Mar 2000 (NSW); Lime Kilns, 17 km from Bathurst, Carter sn, 12 Aug 2000 (NSW). North Western Slopes: upper tributary of Peel R, May s.n., 29 Sep 1978 (NSW A 3125); Moonbi, Skinner 0069, 21 May 2000 (NSW); "Iolanthe", 25km W of Garah, Solling 455, 6 Apr 1973 (NSW); White Gum Lookout, Warrumbungle National Park, Entwisle 3030, 8 Jul 2000 (NSW). Central Western Slopes: Dart Brook, Scone-Merriwa Rd, $10 \mathrm{~km}$ by road from Scone, Entwisle 2868, 17 July 1997 (MEL). South Western Plains: Yelkin St. For., Rankine Springs Rd, 18 km S of Lake Cargelligo, Jobson 6871, Arnold $\mathcal{E}$ Porter, 19 Nov 2000 (NSW); Swan Hill-Balranald Road, near Lake Tooim, Coveny 18736, Oct 2000 (NSW). Far Western Plains: Kinchega National Park, Cherry 302, Hill \& Orme, 2 Oct 2000 (NSW).

Victoria: Mornington Peninsula, Sorrento, Main s.n., 5 Jan 1995 (MEL 2028594); Round Lake, NW of Black Flat, Beauglehole 28386, 16 Sept 1968 (MEL). Wyperfeld National Park, Round Lake, Vollebergh s.n., 17 Mar1985 (MEL 1050418); Horsham, Savage s.n., 4 Oct 2000 (NSW);Mahogany Walk, $6 \mathrm{~km}$ W of Warrnambool, L \& G Kraft s.n., 28 Dec 1999(NSW).

Tasmania: Penquite near Launceston, Gunn, 2 Dec 1848 (NSW A3156). 
South Australia: Highbury, Skinner 0275, 23 Dec 2000 (NSW); Lady Bay, Normanville, Skinner 0291, 14 Sept 1977 (NSW); Bunyeroo Gorge, near Wilpena Pound, May s.n., Dec 1965 (NSW), Drouet (1978) citing this collection, as N. commune, recorded it as New South Wales in error.

Western Australia: Eyre Highway, 110 km W of Caiguna Tank, Bratt 67/251, 6 Oct 1967 (HO).

7d. Nostoc verrucosum Vaucher ex Bornet \& Flahault, Ann. Sci. Nat., Bot., sér.7, 7: 216 (1888).

Colony usually a globose flabbellate sack or lamellate crust, rubbery, dirty green to blackish, from a few mms to several $\mathrm{cms}$ in extent; trichomes with visible sheaths in outer parts of colony, and grading from densely aggregated at margins to more open towards the inside, often spiralled or twisted, often quite long; cells barrel-like to subglobose, L/D 0.8-1.2, (2.4-)3.0-4.8 $\mathrm{\mu m}$ diam.; heterocytes intercalary or falsely terminal on the short trichomes, ovate (5-)6.0-7.2 $\mu \mathrm{m}$; akinetes, when present, paired or forming short moniliform sequences in trichomes, and larger in dimensions than vegetative cells, subglobose to ovate, L/D 1.5, c. 5 um diam. (Fig. 5 j-1).

Distribution and ecology: cosmopolitan. Found in creek beds, shallow streams and on waterfalls, as well as moist paths in rainforest, usually associated with alkaline soil and water. In Australia, previously recorded only from Queensland (Day et al. 1995; Entwisle \& Nairn 1999).

Notes: when encountered in the field, N. verrucosum is often velvety to touch, because of the warty surface, but is otherwise hard to distinguish from other species with a spreading habit. The distinction from $N$. commune based on the occurrence and morphology of the akinetes appears to be useful, although they may be absent in some specimens of $N$. verrucosum. Specimens sometimes show the sheath around the outer trichomes best when the surface of the colony appears to have solidified more than usual, making this a less than reliable character, as both $N$. commune and $N$. pruniforme may also show it. The distribution of trichomes and their length is one of degree, but consistent within the specimens cited; as such it may be ecologically rather than genetically based. Mollenhauer et al. (1999) place importance on $N$. verrucosum plants remaining permanently moist in the field, whereas N. commune is able to withstand periods of desiccation.

Australian material has heterocytes larger than usually described for $N$. verrucosum.

Specimens examined: Queensland: D'Aguilar Range, Northbrook Ck, Mt Glorious-Dundas Rd, Entwisle 2227, 5 Sept 1993 (MEL).

New South Wales: North Coast: Woodenbong Ck, Old Koreelah, crossing near town on road to Mt Barney, Entwisle 2810, 15 July 1997 (MEL); Dorrigo National Park, 9 km by road S of Dorrigo, $6 \mathrm{~km}$ SSW of Dorrigo (direct), Sherrard Falls, Entwisle 285616 July 1997 (MEL). North Western Slopes: junction of Peel R. and Wombramurra Ck, May, 15 Nov 1977 (NSW A3127); upper reaches of creek, head of Peel R., May s.n., 15 Nov 1977,(NSW A3128); station 1, Chaffey Dam Survey, Peel R., May s.n., 15 Nov 1977 (NSW A3129); 27 km by road from Merriwa, Merriwa-Coolah road, Collaroy Bridge, Krui R., Entwisle 2871, 17 July 1997 (MEL). Central Coast: Ashfield, Skinner 0057, 24 Apr 2000 (NSW). Western Plains: Murray's ricefield, Griffith, May s.n., 6 Dec 1978 (NSW A3122).

7e. Nostoc pruniforme C. Agardh ex Bornet and Flahault, Ann. Sci. Nat., Bot., sér.7, 7: 215 (1888).

Colonies gelatinous to rubbery, up to $4 \mathrm{~cm}$ in diameter, blue-green, green or brown; black and crusty when dry; trichomes of many cells (typically 60-80 cells between heterocytes), sheath close fitting when visible; cells subglobose to barrel-shaped, $2-3 \mu \mathrm{m}$ long, 3-4 $\mu \mathrm{m}$ diam.; heterocytes intercalary or terminal, globose or ellipsoid, usually 1-4 per filament, 5-7 $\mu \mathrm{m}$ long, 5-6 $\mu \mathrm{m}$ diam.; akinetes large, spherical to elliptical and about $10 \mathrm{~mm}$ diam. Hormogonia in irregularly sausage-shaped, thin walled packets, with beaks at both ends, heterocyte in one or more rarely both beaks, hormogonal cells 
slightly smaller and more oval than vegetative cells, in contracted spiral trichomes. Spheres with numerous hormogones observed. (Figs 6, e-h, 7).

Distribution and ecology: cosmopolitan. In Australia attached to rocks in streams or seepage areas, or as spherical vesicles on the floors of waterbodies, or on moist soil on lake verges. Often in drainage areas through cleared land. Although not previously reported from Australia, N. pruniforme is particularly common in streams flowing through farmland with Allocasuarina woodland remnants in New South Wales. Such streams are apparently alkaline, consistent with Prescott's (1951) reporting this species from hard-water streams in North America. A similar habitat preference is shown in Australia, by N. commune (although on soil) and often by N. verrucosum. In the notes that follow his description, Prescott adds that this taxon is commonly responsible for the numerous 'marble-like bodies' found on the bottom or margins of waterbodies from time to time. These marble-like bodies are often encountered at the margins of lagoons or on the faces of waterfalls, but like the rubbery sheets of Nostoc commune, are not often deposited in herbaria. An association of this species and water snails, beneficial to the snails, demonstrated by Dodds and Castenholz (1988), has yet to be noted for Australian material.

Common name: this species and related ones are often referred to as bullets when found in the field in rural New South Wales. In Europe, and in North America, this species is most likely to be the one referred to as Mare's Eggs from medieval times to today. Mollenhauer (1970) gives a detailed list of common names collected by $N$. pruniforme around the world, with some comments on the choice of the specific epithet, as part of a thorough review of the taxon.

Notes: similar to Nostoc pruniforme as described by Prescott (1951) but filament cells slightly smaller in Australian material (3-4 $\mu \mathrm{m}$ cf. 4-6 $\mu \mathrm{m}$ diam). Hormogonal packets, with terminal heterocytes, have been seen in Australian material (Entwisle 1862, Cherry $336,337)$, and the gross form of thalli, as single or clustered 'bullets', is like that reported by overseas workers (Dodds \& Castenholz 1988; Mollenhauer 1970; Mollenhauer et al. 1999). The sheath around some trichomes close to the surface in some thalli is conspicuous, and rather more narrow than that in $N$. commune. Mollenhauer (1970) outlines the life history of N. pruniforme. Cherry 336, 337 showed stages from the sausage-shaped hormogonia through the "N. sphericum" clear spheres to solid bullets, massed together rather like caviar. These represent many steps in that life history.

Among our collections we may have representatives of two distinct morphological forms, often from the same site. In our interpretation of $N$. pruniforme we have included both those specimens in which there were discrete, often globular colonies, and those with coalescent colony masses eventually having a spreading form (as in $N$. verrucosum) but with trichomes with dimensions close to the N. pruniforme kind. Such colonies may be soft and friable, breaking into small more or less globular fragments, while those that remain discrete spheres may be tough and rubbery or even gravel-like.

Specimens examined: Queensland: Murray R, Murray Falls, in river below falls, $25 \mathrm{~km}$ NW of Cardwell, off Bruce Highway (Cardwell-Tully), Entwisle 2342a, 12 Sept 1993 (MEL); Souita Falls, $12 \mathrm{~km}$ ESE of Millaa Millaa, tributary of Beatrice R, Entwisle 2287, 10 Sep 1993 (MEL); Rocky Springs, W of Eulo, Ponder E Colman 11Q84, 7 Sep 1984 (NSW).

New South Wales: North Coast: Ellenborough Falls, Ellenborough R., $2.5 \mathrm{~km} \mathrm{~N}$ of Elands, $29 \mathrm{~km}$ NNW of Wingham, Entwisle 1862, 10 Feb 1991 (MEL 2046775); Little Murray R., falls below bridge, Tyringham Road near Dorrigo, Skinner 0140, 23 May 2000 (NSW); 8.4 km from Old Grevillia on Findon Creek Road, Long Ck (flows into Findon Creek), Entwisle 2816, 2817, 15 July 1997 (MEL). Northern Tablelands: Karuah R., upper part of Chichester State Forest, Barrington Tops area, Entwisle 1956, 9 Feb 1991 (MEL); Polblue Ck, Horse Swamp Camping Area, Tubrabucca Rd crossing, Stewart Brook SF, Entwisle 2940, 10 Jan 1999 (NSW); Apsley Falls, Apsley R., Oxley Wild 
Rivers National Park, Skinner 0204, 25 May 2000 (NSW); Bergen Op Zoom Ck, 8km NE of Walcha, Skinner 0198, 25 May 2000 (NSW); Surveyor Ck, Walcha Road, May s.n. , Dec 1968 (as N. sphaericum Vaucher ex Bornet \& Flahault, det. Drouet (May, 1978)) (NSW A3132); Chaelundi Ck, Chaelundi Rest Area, Guy Fawkes River National Park, Skinner 0116, 23 May 2000 (NSW); Wollomombi R, bridge on Waterfall Way, Skinner 0191, 24 May 2000 (NSW). Central Coast: Sydney International Rowing Centre, Penrith Lakes, Skinner 0045, 11 Mar 2000 (NSW); Blarney Ck, Wattagan National Park, Cherry 336, 337, 4 Nov 2000 (NSW). South Coast: Chalkhills Ck, Rats Valley Road, off Chalkhills Road, 11 km WNW of Pambula, Entwisle 1962, 5 Feb 1991 (MEL); Yowrie R., Yowrie, Skinner 0246, 13 Jul 2000; Illawarbra Ck, Wandella State Forest, Yowrie Road, W of Cobargo, Skinner 0251, 13 Jul 2000; Southern Tablelands: Sawpit Ck, Jindabyne - Mt. Kosciuzko Rd, Entwisle 1580, 12 Nov 1988 (MEL).

Victoria: Fiddlers Green Ck, Cann Valley Highway, 34 km from Cann River township, Entwisle 1843, 4 Feb 1991 (MEL).

7f. Nostoc gelatinosum Schousboe ex Bornet \& Flahault, Ann. Sci. Nat., Bot., 7s, 7: 199 (1888).

Colonies rather fluid gelatinous spreading crusts, yellowish brown; sheathed trichomes of cylindrical cells, L/D 1-2.5, 2.5-3.0 $\mu \mathrm{m}$ diam.; intercalary or terminal heterocytes, cylindrical to ellipsoid, 7.0-8.0 $\mu \mathrm{m}$ long,2.5-3.0 $\mu \mathrm{m}$ diam.; akinetes cylindrical, ellipsoid or even reniform spiny-walled, 8.5-12 $\mu \mathrm{m}$ long, 4.5-5.5 $\mu \mathrm{m}$ diam, 2, 3 up to 7 in a series, either apparently replacing the heterocyte or forming independently of it. (Fig. 5, g-i).

Distribution and ecology: cosmopolitan. The present specimen collected among sedges and Restionaceous plants in the seepage between a hanging bog and a rapidly flowing stream.

Notes: while the occurrence of spiniferous akinetes is remarkable in the genus, Geitler (1932) includes the taxon without particular comment, along with N. ellipsosporum Rabenh. and N. spongiforme C. Agardh. There are resemblances to Anabaenopsis, but there is no evidence of paired heterocytes, the trichomes do not arrange themselves in crescents or spirals, and the number of akinetes is frequently three or more in a sequence (see Hindák 1988; Komárek \& Anagnostidis 1989). This collection also shows affinity to Cylindrospermum but differs on a number of points including the intercalary heterocytes and the often well developed sheath. Until further collections can be made and some cultural observations completed, it appears best to include the record under the name above, albeit with misgivings about its generic position.

Specimen examined: New South Wales: Northern Tablelands: Bullock Creek, hanging bog, Skinner 0178, 24 May 2000 (NSW).

\section{Comments}

Few of these organisms are rare, rather they are seldom collected. As noted above for Rivularia, many of these taxa may be overlooked by collectors more interested in their hosts or associated aquatic plants. Others like Dichothrix are frequently dismissed as stains or dirt on stonework and removed without enquiry into their biological nature.

Most home gardeners, farmers and bushwalkers will have encountered Nostoc from time to time. Lawns after heavy rain often display rubbery crusts. Hard dark green shotgun pellet sized 'bullets' turn up, sometimes in millions, round the edges of swamps. Rocks in creek beds and waterfalls show slippery, rubbery skins. People seldom collect such things. Recent publicity about Nostoc commune in gardening circles in Australia resulted in numerous phone calls to the authors, and collections from inland and coastal areas throughout the eastern states. 


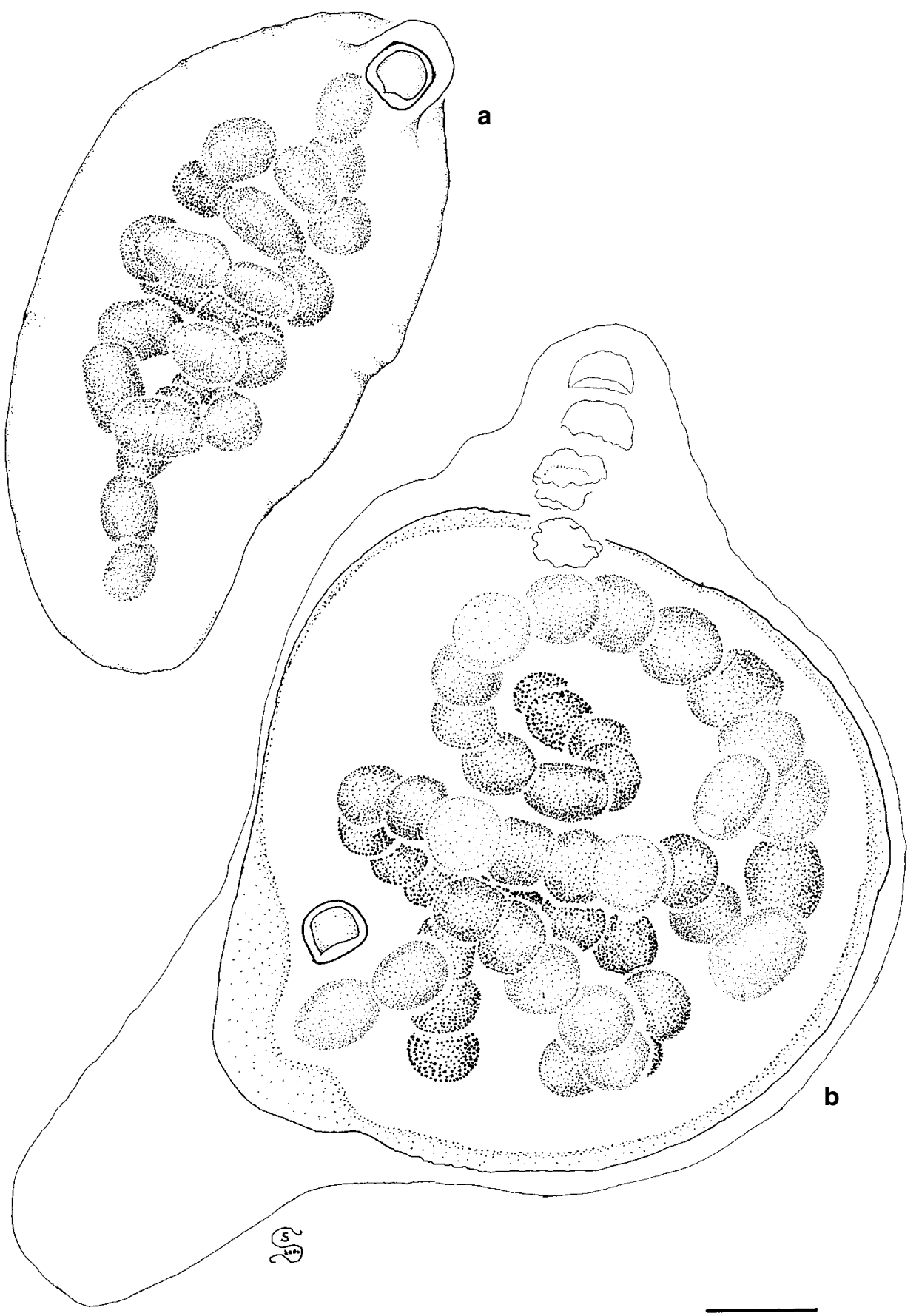

Fig. 7. Nostocaceae: Nostoc pruniforme a. hormogonium germinating; b. New spherical colony inside old hormogonial sheath (Cherry 337). Scale bar $=10 \mu \mathrm{m}$. 
Some species are considered good enough to eat or may have other conservation or commercial prospects. Even so there are very few specimens of most taxa discussed here in Australian herbaria, many catalogued at genus level only. There is a very real need for wider collection, and economic and ecological investigation of the group in Australia. With the encouragement of the New South Wales Biodiversity Strategy we have made a start through this floristic survey, and hope that this account will prompt thorough taxonomic reviews of these taxa.

\section{Acknowledgments}

The authors wish to acknowledge the financial support from the National Parks and Wildlife Service through the New South Wales Biodiversity Strategy, and the staff and Directors of those Herbaria that loaned material for inclusion in this paper. We are most grateful to those numerous members of the general public and our colleagues, especially Wayne Cherry, who brought us collections, and the Richmond River Historical Society for help in identifying Playfair's type locality for Cylindrospermum rectangulare. We would also like to thank Professor Malcolm Potts for his DNA analysis, and Dr David Daintree for help with Latin diagnoses.

\section{References}

Anagnostidis, K. \& Komárek, J. (1990) Modern approaches to the classification system of Cyanophytes 5-Stigonematales. Arch. Hydrobiol. Suppl.-Bd 86 (Algological Studies 59): 1-73.

Bailey, F.M. (1913) Comprehensive catalogue of Queensland Plants. (Govt Printer: Brisbane).

Baker, P.D. \& Fabbro, L.D. (1999) A Guide to the Identification of Common Blue-Green Algae (Cyanoprokaryotes) in Australian Freshwaters. (CRC Freshwater Ecology: Thurgoona NSW).

Bornet, E. \& Flahault, C. (1886-1888) Revision des Nostocacées hétérocystées contenues dans les principeaux herbiers de France. Ann. Sci. Nat., Bot., sér. 7, 3: 323-380 (1886), 4: 343-373 (1886), 5: 51-129 (1887), 7: 171-262 (1888).

Borge, O (1911) Algologische Notizen. 6. Süsswasseralgen aus Queensland. Bot. Not., (1911): 197-207.

Brock, M.A. (1986). Adaptation to fluctuations rather than to extremes of environmental parameters. Pp.131-140 in P. De Decker \& W.D. Williams (eds) Limnology in Australia (CSIRO/Junk: Canberra/Dordrecht.)

Day S.A., Wickham R.P., Entwisle T.J. \& Tyler P.A. (1995) Bibliographic Checklist of Non-marine Algae in Australia. (Flora of Australia Supplementary Series No. 4; ABRS: Canberra).

Desikachary, T.V. (1959) Cyanophyta (I.C.A.R. Monographs on Algae: New Delhi).

Dodds, W.K. \& Castenholz, R.W. (1988) Effects of Grazing and Light on the Growth of Nostoc pruniforme (Cyanobacteria). Br. Phycol. J. 23: 219-227.

Dodds, W.K., Gudder, D.A. \& Mollenhauer, D. (1995) The ecology of Nostoc. J. Phycol. 31: 2-18.

Drouet, F. (1978) Revision of the Nostocaceae with Constricted Trichomes. Beihefte zur Nova Hedwigia, 57. (J Cramer: Germany)

Entwisle, T.J. \& Nairn, L. (1999). Freshwater Algae - Census of Freshwater Algae in Australia (version 1). http://plantnet.rbgsyd.gov.au/PlantNet/fwalgae.htm

Franquemont, C., Franquemont, E., Davis, W., Plowman, T., King, S.R., Sperling, C.R. \& Niezgoda, C. (1990) The Ethnobotany of Chinchero, an Andean Community in Southern Peru. (Fieldiana, Botany New Series No. 24).

Gao, K. (1998) Chinese studies on the edible blue-green alga, Nostoc flagelliforme: A review. J. Appl. Phycol. 10: 37-49.

Geitler, L. (1932) Cyanophyceae. In Rabenhorst, L (ed.) Kryptogamenflora von Deutschland, Oesterreich und der Schweiz. vol. 14.(Akad. Verlagsges.: Leipzig).

Hindák, F. (1988) Planktic species of two related genera Cylindrospermopsis and Anabaenopsis from Western Slovakia. Arch. Hydrobiol. Suppl.-Bd 80 (Algological Studies 50-53): 283-302.

Komárek, J. (1989) Studies of the Cyanophytes of Cuba 4-6. Folia Geobot. Phytotax. 24: 57-97. 
Komárek, J. \& Anagnostidis, A. (1989) Modern approaches to the classification system of Cyanophytes. 4 Nostocales. Arch. Hydrobiol. Suppl.-Bd 82 (Algological Studies 56): 47-345.

Komárek, J. \& Anagnostidis,K. (1999) Cyanoprokayota, 1 in Ettl, H. Gärtner, G. Heynig, H. \& Mollenhauer, D. (eds) Süßzasserflora von Mitteleuropa. vol. 19 (Gustav Fischer: Jena).

Lembi, C.A. \& Waaland, J.R. (1988) Algae and Human Affairs (Cambridge UniversityPress: Cambridge).

McLeod, J.A. (1975) The Freshwater Algae of Southern Queensland. Unpublished Ph.D thesis, University of Queensland.

Mollenhauer, D. (1970) Beiträge zur Kenntnis der Gattung Nostoc.1. Abh. Senckenberg. Naturforsch. Ges. 524: 1-80.

Mollenhauer, D., Bengtsson, R. \& Lindstrøm, E-A. (1999) Macroscopic cyanobacteria of the genus Nostoc: a neglected and endangered constituent of European inland aquatic biodiversity. Eur. J. Phycol 34: 349-360.

Mollenhauer, D., Büdel, B. \& Mollenhauer, R.(1994) Approaches to species delimitations in the genus Nostoc Vaucher 1803 ex Bornet et Flahault 1888. Arch. für Hydrobiol., Suppl.-Bd 105, (Algological Studies 75):189-209.

Playfair, G. I. (1915) Freshwater algae of the Lismore district: with an appendix on the algal fungi and schizomycetes. Proc. Linn. Soc. NSW 40: 310-362.

Playfair, G.I. (1917) Freshwater Algae. in J.H. Maiden \& E.Betche, A Census of New South Wales Plants, Suppl. 1.(Government Printer: Sydney).

Playfair, G. I. (1918) New and rare freshwater algae. Proc. Linn. Soc NSW 43: 497-543.

Potts, M. (1997) Etymology of the Genus Name Nostoc (Cyanobacteria). Int. J. Systematic Bacteriology 47: 584.

Prescott, G. W. (1951). Algae of the Western Great Lakes Area, Exlusive of Desmids and Diatoms. (Cranbrook Institute of Science, Bulletin No. 31: Cranbrook Press, Michigan).

Scott, A.M. \& Prescott, G.W. (1958) Some freshwater algae from Arnhem Land in the Northern Territory of Australia. Pp 9-136 in R.L. Spect and C.P. Mountford (eds.) Records of the AmericanAustralian expedition to Arnhem Land, vol. 3. (Melbourne University Press: Melbourne).

Sheath, R.G. \& Cole, K.M. (1996) Stream macroalgae in the Fiji Islands: a Prelimimary Study. Pacific Science 50: 46-54.

Womersley, H.B.S. (1984) The Marine Benthic Flora of Southern Australia. Part 1. (Govt. Printer: South Australia).

Manuscript received 9 February 2001

Manuscript accepted 13 August 2001 